\title{
1 Revised map of European aeolian deposits derived from soil texture data
}

2 Pascal Bertran ${ }^{1,2^{*}}$, Mathieu Bosq ${ }^{2}$, Quentin Borderie ${ }^{3}$, Céline Coussot ${ }^{4,5}$, Sylvie Coutard ${ }^{6,5}$, Laurent

3 Deschodt $^{7,6}$, Odile Franc ${ }^{8}$, Philippe Gardère ${ }^{9,10}$, Morgane Liard ${ }^{11}$, Patrice Wuscher ${ }^{12,13}$

$4 \quad{ }^{1}$ Inrap, 140 avenue du Maréchal Leclerc, 33130 Bègles, France

2 PACEA, Université de Bordeaux-CNRS, bâtiment B2, allée Geoffroy-Saint-Hilaire, 33605 Pessac, France

$7 \quad{ }^{3}$ Direction de l'aménagement, Conseil départemental d'Eure-et-Loir, 28028 Chartres, France

$8{ }^{4}$ Inrap, 3-5 rue René Cassin, 28000 Chartres, France

${ }^{5}$ UMR 8591 CNRS, Laboratoire de Géographie Physique, Environnements Quaternaires et actuels, 1 Place A. Briand, 92195 Meudon Cedex, France

${ }^{6}$ Inrap, 32 avenue de l’Etoile du Sud, 80440 Glisy, France

${ }^{7}$ Inrap, 11 rue des Champs, 59650 Villeneuve-d'Ascq, France

${ }^{8}$ Inrap, 12 rue Maggiorini, 69500 Bron, France

${ }^{9}$ Inrap, 148 Avenue André Maginot 37100 Tours, France

${ }^{10}$ UMR 7324 CNRS Citères - LAT, 35 Allée Ferdinand de Lesseps, 37200 Tours, France

${ }^{11}$ Inrap, 525 avenue de la Pomme de Pin, 45590 Saint-Cyr-en-Val, France

${ }^{12}$ Archéologie Alsace, 11 Rue Jean-François Champollion, 67600 Sélestat, France

${ }^{13}$ Laboratoire Image Ville Environnement, Université de Strasbourg-CNRS, 3 rue de l'Argonne, 67000 Strasbourg, France

* Corresponding author.

E-mail address: pascal.bertran@inrap.fr (P. Bertran)

\section{Abstract}

European aeolian deposits have been mapped using the LUCAS topsoil texture database and the location, thickness and grain size mode of loess sections described in the literature have been compiled. The map, in fairly good agreement with those based on a classical geological approach, has the advantage of being of equal precision for the whole study area and makes it possible to highlight grain size gradients. It shows three main types of aeolian systems, i.e. systems associated with ice sheets (FIS, BIIS, AIS) and the rivers they feed, continental systems related to the erosion of sedimentary rocks, and coastal systems. Each aeolian system is comprised of a band of coversands of varying extent close to the sources and bands of sandy loess and loess away from the sources. The thickness of loess is highly variable throughout Europe. The areas of greatest accumulation are associated with the rivers draining the AIS (Rhine, Danube, Rhône). The Middle Danube, which combines sources of glacial origin (AIS) and local sources, constitutes the main accumulation area in Europe. Conversely, continental and coastal systems generated only limited loess cover. The 
latitudinal gradient of vegetation probably played an important role in loess sedimentation during the LGM. Weak interference between particle transport and vegetation (periglacial desert in the sand belt, cryptogamic crusts and steppe in the north European loess belt) allowed for particle sorting through aeolian transport to develop. The loess band is extensive in low-relief areas and is typified by a low sand content. In southern Europe, on the other hand, the capture of saltating and suspended particles by the shrubby steppe vegetation led to the dominant accumulation of sandy loess near sources.

Keywords: loess, coversand, cartography, Europe, LUCAS topsoil database

\section{Introduction}

Along with the development of databases and GIS software, the cartography of aeolian deposits in Europe has given rise to a great deal of work over the past decade due to a rising interest in various fields, particularly agriculture and the reconstruction of Quaternary glacial environments. The cartography has been achieved using two main types of methods: (1) the compilation of regional maps based on a conventional geological or pedological approach, and (2) the use of databases on soil texture interpolated from a dense mesh of measurement points, sometimes coupled with other variables. Among the first type of maps, the most notable are those produced by Wagner et al. (2011) and Lehmkuhl et al. (2018a) for Germany, Prognon et al. (2011) for France, Lindner et al. (2017) and Lehmkuhl et al. (2018b) for the Pannonian Basin (Croatia, Hungary, Serbia), and Jipa (2014) for the Lower Danube Basin (Romania and Bulgaria). These maps were then compiled in order to produce a homogeneous document at a continental scale (Haase et al., 2007; Lehmkuhl et al., 2021). The second type of method has been developed more recently using the topsoil texture database provided by the European project Land Use and Cover Area Frame Statistical Survey (LUCAS, Totth et al., 2013; Ballabio et al., 2016) and the French Donesol project of the Institut National de Recherche Agronomique (INRA). The resulting maps cover French regions (Sitzia et al., 2017; Bosq et al., 2018) and the European Union (Bertran et al., 2016). A similar approach, coupled with airborne gamma-ray radiometric data, was proposed by Chen et al. (2020) for a small region (Beauce) in the Paris Basin, France.

Both methods have their own advantages and limitations. The main drawbacks of the conventional cartographic approach lie in the heterogeneity of the data used depending on the country (geological or pedological maps), in the heterogeneity of the thickness criteria for the mapped deposits and, finally, in the difficulties inherent to the mapping of discontinuous Quaternary formations because of the contrasting interest shown by the authors in surface deposits at the expense of bedrock. This factor is clearly perceptible by looking at adjacent sheets of the French 1:50,000 geological map, where loess areas can stop abruptly when crossing sheet boundaries. Therefore, the accuracy and reliability of the maps remain variable from one region to another.

In comparison, the second type of cartography has the advantage of being established with homogeneous data over the whole territory under consideration. It also has the advantages of (1) proposing a map of equal precision for all regions, and (2) showing particle size gradients, which provide important information on the origin of particle sources. The limits are mainly those inherent to the interpolation of particle size data from a limited number of observation points. However, the evaluation made by Ballabio et al (2016) for the LUCAS database indicates that the difference 
between predicted and measured texture does not exceed $10 \%$ for low-altitude areas. Another uncertainty lies in the delimitation of the textures corresponding to aeolian deposits. For the map proposed by Bertran et al (2016), the range of textures measured by the pipette method on loess samples from northern France by Lautridou (1985), similar to the method used in the LUCAS project, was chosen as representative of all European loess. Comparison with the geological maps and the distribution of known loess sections subsequently showed that the extent of loess was largely underestimated in some European regions, particularly in the Rhône valley (Bosq et al., 2018) and southern Germany (Lehmkuhl et al., 2018a). Similar observations can also be made for a large part of southeastern Europe. Finally, another uncertainty exists with the similar textures of non-aeolian deposits (e.g., silt-rich lacustrine or fluvial deposits) with that of loess and the potential erroneous consideration of these deposits. Nevertheless, first evaluations in France through a comparison between field data and the map generated using the LUCAS database have shown that this uncertainty is minimal, due to the particular texture of aeolian deposits (Bertran et al., 2016; Bosq et al., 2018). Aeolian deposits show both a specific texture and a great continuity in the landscape, covering usually many square kilometres without significant textural changes. In contrast, only isolated pixels in areas of sedimentary formations or weathering mantles satisfy the textures used for aeolian deposits. These pixels have been removed though data treatment (see below).

This paper proposes a new cartography of European aeolian deposits based on topsoil texture (LUCAS), using an improved envelope for loess texture and a modified treatment. In parallel, a compilation of data on the thickness of the loess cover has been carried out using sections available in the literature and borehole databases. Information on the particle size distribution of Marine Isotope Stage (MIS) 2 loess obtained by laser granulometry has also been gathered from databases and information provided by various scientists. Goal here is to shed new light on the distribution of Pleistocene aeolian deposits and contribute to a better understanding of the factors that controlled their emplacement.

\section{Methods}

Raster maps of the topsoil (0-20 cm depth) content in clay $(<2 \mu \mathrm{m})$, silt $(2-50 \mu \mathrm{m})$, sand (50$2000 \mu \mathrm{m}$ ) and coarse fragments ( $>2 \mathrm{~mm}$ ) interpolated over the entire territory of the European Union by Ballabio et al. (2016) from the LUCAS database (available on the European Soil Data Centre website, eusoils.jrc.ec.europa.eu/data.html) were used as starting data for the analysis. In this database, the texture was measured using the pipette and sieving method. The target texture for three categories of aeolian deposits (coversands, sandy loess and loess) was determined using the following method. The texture of 500 randomly distributed points in the areas mapped by Lehmkuhl et al. (2018a) in middle and southern Germany as loess with a thickness greater than $2 \mathrm{~m}$ was extracted from the LUCAS rasters. The area corresponding to the textures obtained (Fig. 1A), minus the most sandy part (the boundary between loess and sandy loess was set at $37 \%$ sand), provides the target texture for the 'Central European loess' category (Fig. 2, Table 1). The choice of a 37\% sand limit, slightly higher than that used by Haase et al. (2007), i.e. 30\%, is motivated by the difference between the minimum sand size for LUCAS $(50 \mu \mathrm{m})$ and for Haase et al. $(63 \mu \mathrm{m})$. It also enables us to obtain categories whose areas are roughly equivalent in a sand-silt-clay diagram. The coarse fragment content was limited to $13 \%$ as for Bertran et al. (2016).

The texture of loess from northern France from Lautridou (1985), used by Bertran et al. (2016) to define the target texture of loess, is characterised by a higher percentage of silt on average and a 
very low percentage of sand, i.e., less than $20 \%$ for the majority of the sites analysed (Fig. 1B). Comparison between the composition of Lautridou's samples and the LUCAS texture of 500 points randomly distributed in the area mapped as loess with a thickness greater than $4 \mathrm{~m}$ by the same author shows good agreement between the texture ranges and indicates that loess in that region is fairly homogeneous and contains little sand. Therefore, the target texture of the Northern European Loess Belt (NELB) has been extended towards the silt pole compared to that of central Europe (Fig. 2). For Brittany, where loess can be mixed with sand derived from granite weathering, the envelope of Lautridou's samples has been retained for the loess target texture.

The 'Central European loess' texture was then slightly modified for southern European regions, so as to include as many of the LUCAS textural data points as possible corresponding to the loess outcrops listed in the literature, while also keeping the window as narrow as possible. Comparison with the distribution of known loess outcrops in the Rhône valley in France (Bosq et al., 2018) and the available maps for Italy (Cremaschi et al., 2015; 'Pleistocene silts' from the 1:1,000,000 geological map, onegeology, http://www.europe-geology.eu/onshore-geology/) shows that the target texture of the 'Central European loess' significantly underestimates the extent of loess. In both areas, the main issue is related to the high percentage of coarse fragments in the topsoil, which exceeds $13 \%$ in the majority of cases (Fig. 3A). The abundant coarse fraction can have two main origins: (1) the presence of anthropogenic remains (shards, various debris) left by the dense occupation of these areas during the Holocene, (2) the presence of carbonate concretions favoured by the Mediterranean climate and mixed with the topsoil because of ploughing, erosion or colluviation. Observations in the Rhône Valley by Bosq et al $(2018,2020$ a) have shown that the second factor plays an important role. The upper limit of coarse fragments was therefore raised to $18 \%$ for Italy and $20 \%$ for the Rhone valley following Bosq et al. (2018). However, such an adjustment increases the risk of improperly classifying as loess other deposits or mixtures of loess and coarser material such as colluvium.

Although loess accumulations forming part of the NELB were mapped by Catt $(1977,1985)$ in the UK over large areas, few pixels were found to meet the target loess texture, primarily because of a percentage of coarse fragments greater than $13 \%$. Observations by Murton et al (2003) in Kent suggest that the loess cover, generally less than $2 \mathrm{~m}$ thick, has been strongly affected by periglacial processes. In this area, loess forms pockets surrounded by involutions of chalk diamicton (brecciated chalk substratum). The involutions reach the surface and probably explain the abundance of coarse debris in the topsoil. Consequently, the maximum content of coarse fragments was set at $18 \%$.

Finally, an adjustment was made for the maximum allowable percentage of clay in loess from southern Europe, since the typical soils of these regions, respectively Mediterranean Cambisols (Rhône valley, Italy) and Chernozems (Bulgaria, Romania), are richer in clay than the Luvisols and Cambisols of the rest of Europe, where weaker weathering and stronger clay eluviation take place in the topsoil (Fig. 3B). An additional factor that may have accounted for higher clay content in southern Europe is the contribution of clay-rich dust from the Sahara, although this contribution is still debated (e.g., Varga et al., 2016; Bosq et al., 2020b). The threshold has been set at $33 \%$ instead of $30 \%$.

The LUCAS texture points corresponding to the sections of aeolian sand described in Aquitaine (Sitzia et al., 2017; Bertran et al., 2020) made it possible to define a target texture for coversands (Fig. 1A). The upper limit of coarse fragments was set at $12 \%$. This target texture was considered 
representative of all European coversands. The compositions between coversands and loess define the category of 'sandy loess'. As with loess, adjustments were made regionally according to the percentage of clay and coarse fragments (Fig. 2, Table 1).

The extraction of pixels ( $500 \mathrm{~m} \times 500 \mathrm{~m}$ ) satisfying the target textures by combining the LUCAS rasters for sand, silt, clay and coarse fragments was carried out region by region using the software QGIS version 3.10. In order to generate more continuous map units and to reduce the noise related to local texture variations, the value of each pixel (1: satisfies the target texture, 0 : does not satisfy this texture) was recalculated from the average of the closest pixels and values below a threshold of 0.5 were eliminated. The areas corresponding to Holocene formations in the 1:1,000,000 European geological map, modified from the data provided by Lehmkuhl et al. (2018b) for several countries and the Carte du Régolite (Prognon et al., 2011) for France, were then subtracted. The areas of northern Europe covered by the Fennoscandian (FIS) and British-Irish (BIIS) ice sheet at 15 ka (Clark et al., 2012; Stroeven et al., 2016) were also subtracted. The resulting rasters were converted into polygons and then assembled into a single file for the European Union. Polygons with an area of less than four pixels were finally eliminated.

The location of the loess sections mentioned in the literature was gathered into a point file, either from the coordinates provided by the authors or, in few cases, by georeferencing the published maps. Depending on the sources, these locations have a varying precision. For France, the boreholes listed in the Banque du Sous-Sol (BSS) of the Bureau des Recherches Géologiques et Minières (BRGM) and located in areas with a loess cover were exploited, although not exhaustively. Data from rescue archaeology (Bertran et al., 2011, 2016; Font et al., 2016; Borderie et al., 2017; Sitzia et al., 2017; Gardère and Djemmali, 2018; Coutard et al., unpublished) and various academic works were also taken into account. Overall, the network of observation points is relatively dense in France $(\mathrm{N}=1707)$, much looser for the rest of Europe $(\mathrm{N}=138)$. For each point, the fields completed are (1) the total thickness of the loess cover, (2) the thickness of the Last Glacial loess cover, i.e. all the loess located above the Interglacial - Early Glacial palaeosol complex, and (3) the main mode of the grain size distribution of loess from Marine Isotopic Stage (MIS) 2. When several samples were available for MIS 2, only one representative sample (i.e. with an intermediate particle size distribution between the extremes) was chosen.

\section{Results}

\subsection{Comparison between the new map and previous maps}

Overall, the visual concordance between the new map (Fig. 4) and the map by Lehmkuhl et al. (2021) is good (Fig. 5). There is a $55 \%$ overlap between the loess and sandy loess areas mapped by the latter authors and those of the new map. An important part of the discrepancies comes from the peripheral areas of the main aeolian accumulations. Significant differences also appear for some regions, e.g., Aquitaine, where the map by Lehmkuhl et al. (2021) does not show any loess, as well as the French side of the English Channel (Brittany-Normandy) and the Po basin where loess is much more extensive in the new map. Similarly, the sandy loess category forms a more continuous band south of the North European coversands. Another noteworthy point is the small extent of sand on the map by Lehmkuhl et al (2021). Large areas of Hungary mapped as coversands by both Sebe et al. (2011) and the present study appear as sandy loess in Lehmkuhl et al. (2021), especially around the 
towns of Kecskemet and Debrecen. In total, loess, sandy loess and coversands cover an area of about $382419 \mathrm{~km}^{2}, 107111 \mathrm{~km}^{2}$ and $372119 \mathrm{~km}^{2}$ respectively on the new map presented here.

The Cotentin peninsula on the French side of the English Channel was the subject of numerous field observations using trenches and augering by Coutard (2003) and enables a precise comparison to be made between available maps and the location of the points where the presence or absence of loess has been proved (Fig. 6). Compared to the other maps, the new one scores better (ca. 86\%) in classifying as loess those points where the presence of loess is actually confirmed by field studies (Fig. 7), largely because this category is more widely represented. The average loess thickness in this map unit determined from all the observation points is $0.54 \mathrm{~m}$, while it is only $0.20 \mathrm{~m}$ in areas not mapped as loess. When only the points where loess has been observed are taken into account, the average thickness reaches $1.55 \mathrm{~m}$ in the areas mapped as loess, while it reaches only $1.16 \mathrm{~m}$ outside. Unexpectedly, the latter values are reversed for the other maps (BRGM geological map 1:50,000, Lehmkuhl et al., 2021), i.e. the thickest loess sections are located outside the mapped loess areas.

The resulting map shows relatively independent aeolian systems, each characterised by the juxtaposition of sand, sandy loess and loess areas. These systems are detailed separately in the following paragraphs.

\subsection{Northern European Sand Belt (NESB) and Loess Belt (NELB)}

Northern Europe is covered by a wide band with a dominant texture of aeolian sand approximately bounded by the parallel $\mathrm{N}^{\circ} 0^{\circ}$ in Poland and $\mathrm{N}^{\circ} 2^{\circ}$ in the Netherlands and Belgium. This band matches well with the coversands and continental dunes mapped by Koster (1988) and Zeeberg (1998), referred to as the 'European Sand Belt'. It suggests a much greater extension and continuity of the aeolian sand cover than is indicated by the geological maps (Lehmkuhl et al., 2016, 2021) probably because it is thin, often less than $1 \mathrm{~m}$ (Kasse, 1997, 2002). Comparison with the 1:1,000,000 geological map of Europe shows that the southern limit of sand coincides with the extent of Upper and Middle Pleistocene tills and fluvioglacial deposits from Poland to the Netherlands, as already noted by Koster (2005) (Fig. 8), and suggests a genetic relationship between glacial outwash and coversands (Kasse, 1997; Koster, 2005). This low-altitude zone ( $<100 \mathrm{~m}$ asl) is also typified by very little contrast in relief, which is favourable to the progression of sand by saltation over large areas (Pye, 1995; Mason et al., 1999). The extensive low-lying plains in the southern Netherlands and Belgium probably accounts for the spread of coversands there well beyond the limit reached by the Quaternary glaciers, from sources located in today's North Sea (Vandenberghe and Krook, 1981; Kasse, 1997). The sand belt continues westwards to East Anglia in the UK (Catt, 1977; Bateman, 1995), where the map shows only discontinuous patches due to the thin cover and disturbance by periglacial processes favoured by the frost-susceptible chalk substratum (Murton et al., 1995).

The sand belt is bordered along its entire southern length by a band of sandy loess of varying width, from less than $10 \mathrm{~km}$ (Germany, Poland) to more than $50 \mathrm{~km}$ (Belgium), which gives way still farther south to loess forming a blanket 20 to $40 \mathrm{~km}$ wide in the east to more than $100 \mathrm{~km}$ wide in the west (Belgium and northern France). It can be noted that rivers flowing from south to north in Germany and Poland, e.g. the Leine, the Saale, the Lausitzer Neisse and the San, cross the aeolian bands without significant disturbance of the latter. The juxtaposition of these belts reflects the size sorting of the particles transported in suspension and suggests the same sources as for the coversands. This is consistent with the potassium-rich and relatively calcium-poor geochemical composition of loess 
from Poland and northern Germany, which is similar to that of the felsic rocks of the Scandinavian Shield (Bosq et al., 2020b; Skurzynski et al., 2020). The same holds true further east for loess in the Dnieper basin in Ukraine (Buggle et al., 2008), not shown on the map. The composition becomes richer in carbonates and resistant minerals westwards (Belgium, France) following the contribution of alluvial deposits from the Rhine and Seine.

The spatial extent of the loess belt is controlled primarily by relief, particularly to the south by mountain ranges such as the Carpathians, the Sudeten Mountains, the Rhenish Schist Massif and the Ardennes. As already pointed out by Bertran et al (2016), loess spreads westwards to the tip of Brittany and indicates that the Manche River (i.e. the river that occupied the English Channel, e.g. Toucanne et al., 2009) fed both by meltwater from the ice sheets and by the rivers Rhine, Seine and Thames, was an important source of particles (Lautridou, 1985). Due to its thinness and discontinuous nature, the loess cover located west of the Seine is underrepresented on available geological maps (e.g., Prognon et al., 2011; Lehmkuhl et al., 2021). Along the English Channel, whose coasts are dominantly bordered by cliffs that formed an obstacle to the progression of saltating sand, coversand and sandy loess are lacking on the currently emerged part of the continent. The small sand patches at the periphery of the Mont-Saint-Michel Bay described by Lautridou (1985), which are associated with ventifacts and sand wedge casts, are an exception. They are not visible on the map, probably due to their discontinuous nature. Some loess sections studied by Coutard (2003) located along the Normandy coast also have a significant sandy fraction (40-60\%).

In detail, there are also areas with sandy loess texture, more rarely loess, within the ESB, which form narrow bands that are increasingly developed eastwards into Poland. These bands run along ice marginal valleys (IMV), in particular the Elbe-Glogow-Baruth IMV (Marks, 2002; Badura et al., 2013) and probably reflect phases of stagnation of the ice front during deglaciation, associated with the northward shift of the aeolian system that followed the retreat of the ice. Loess accumulations, however, remain limited due to the short duration of these phases.

\subsection{Perialpine systems}

Rivers fed by the Alpine Ice Sheet (AIS) were the source of thick aeolian deposits along the adjacent valleys. In spite of the specific properties of each catchment area, the geochemical composition of all perialpine loess is similar and characterised by a high Ca content due to abundant calcareous rocks in the AIS bedrock (Bosq et al., 2020b). Four major rivers have created aeolian systems of significant extent, the Rhine, the Danube, the Rhône and the Po, each of which has a sandy area of limited width near the river and finer deposits away from the river on either side, often with a marked asymmetry. For the Rhine, accumulations develop mainly in the graben upstream of the Rhine-Main confluence (Upper Rhine Graben, URG) as well as further north (Lower Rhine Embayment, LRE) in the congruence zone with the NELB as already shown by Lehmkuhl et al. (2018a). In the URG, the accumulations remain primarily confined to the graben where they cover alluvial terraces. They spread more widely over the plateaus in areas where relief does not exceed $250 \mathrm{~m}$ asl, particularly on the right bank between Karlsruhe and Heidelberg. Geochemistry supports a predominantly Alpine origin (Rhine alluvium) for Nussloch loess (Schatz et al., 2015; Bosq et al., 2020b).

A north-south asymmetry appears clearly in the distribution of aeolian deposits along the Rhône valley, with predominant loess accumulation over fluvio-glacial fans to the north of Valence and sandy loess to the south, associated with dunes and deflation features (yardangs, pans, ventifacts) 
close to the river (Gabert, 1965; Ambert, 2013; Bosq et al., 2018). The transition takes place downstream of valley narrowings between the Massif Central and the Alps, which channeled and accelerated the prevailing winds.

The Po catchment area is largely covered by loess, with a strong asymmetry between the northern and southern banks. Overall, the map presented here suggests that aeolian deposits are more widespread than shown by Cremaschi et al. (2015) and Lehmkuhl et al. (2021). Sandy silt mantles the northern banks of the Po and forms strips along alpine tributaries. These deposits were interpreted as Late Pleistocene fluvial sediments by Italian authors instead of aeolian deposits. Close association of loess and sediments with a sandy loess texture questions, however, such an interpretation. Additional field work would be necessary to solve this issue.

The Danube system is more complex and overlaps with other river systems and with the system of the Pannonian Basin (Hungary, Serbia). The main areas of loess accumulation are located in the upper basin (Upper Danube Basin, UDB: Southern Germany, Austria), the middle course (Middle Danube Basin, MDB) as it crosses the Pannonian Basin (Lehmkuhl et al., 2018b) where the Danube joins the Morava coming from the Bohemian Massif, then the Drava, another Alpine river, and the lower course (Lower Danube Basin, LDB) downstream of the Carpathians (Romania, Bulgaria; Jipa, 2014). In the LDB, sandy loess expands and is mainly distributed at the exit of the Carpathians, along the tributaries, as well as in the downstream course where the Danube flows northwards before its confluence with the Prut. In this sector, the pattern in bands of decreasing grain size away from the river becomes confused and sandy loess extends over more than $80 \mathrm{~km}$ northwest of the Danube.

\section{4. 'Continental' systems}

These systems correspond to outcrops of (often Cenozoic) sedimentary rocks (sand, sandstone, molasse) at the outlet of corridors that channelled the wind. One of the best examples is the Pannonian Basin (Hungary) described by Sebe et al $(2011,2015)$. It comprises successively from upwind to downwind (1) a zone dominated by deflation, where sedimentary rocks are carved by the wind (yardangs, pans, ventifact pavements), (2) coversands and (3) a loess belt. In this basin crossed by the Danube, Alpine (Danube alluvium) and local inputs are closely intertwined and their respective contributions remain difficult to assess (Smalley and Leach, 1978; Wright, 2001). Geochemical data clearly indicate the mixture of different sources, in particular Danube alluvium, alluvial fan deposits from the Carpathians, and dolomite-rich rocks cropping out in the basin (Ujvari et al., 2012).

Similar but smaller systems, combining yardangs, playas and coversands, have been described in Spain in the Ebro basin (Gutiérrez-Elorza et al., 2002), the Duero basin (Bateman and Diéz-Herrero, 2001; Bernat Rebollal and Pérez-Gonzalez, 2008) and the Manchega plain (Bernat Rebollal and PérezGonzalez, 2008). The sandy areas as mapped by these authors are poorly captured by the map presented here, although aeolian sand patches are present in the Duero Basin. Loess patches also occur in the map downwind of the deflation areas in the Ebro Basin, in agreement with Boixadera et al. (2015) and along the Tagus (Wolf et al., 2018, 2019).

Small continental systems also exist in France in the Loire basin between Tours and Orléans where the formations that were the sources of aeolian particles are Eocene to Middle Pleistocene in age (Macaire, 1986; Liard et al., 2017), as well as possibly in Germany around Nuremberg (Triassic). Aeolian accumulations are limited in extent and dominated by coversands and sandy loess. Deflationrelated features are restricted to ventifact pavements. In the Nuremberg area, aeolian sand patches 
are indicated by Lehmkuhl et al. (2021), demonstrating that the Triassic substrate has been affected by deflation during the Pleistocene. The map presented here suggest that the deposits have a sandy loess texture instead of a typical coversand texture (at least in the topsoil) and forms larger patches than shown by Lehmkuhl et al. (2021). This may be an effect of the method used for mapping. Conventional geological approach only takes into account units thicker than one or two metres, whereas much thinner aeolian covers are captured by the approach based on topsoil texture.

\subsection{Atlantic coastal systems}

Several aeolian systems have developed along the Atlantic coast, particularly in southwestern France (Aquitaine, Sitzia et al., 2015, 2017; Bertran et al., 2020) and in the Iberian Peninsula (Gulf of Cadiz, Spain, Zazo et al., 2005, 2008; Aveiro area, Portugal, Granja et al., 2008; Thomas et al., 2008). The progression of sands far inland was made possible during the glacial periods by the absence of coastal relief. The loess belt remains modest in Aquitaine and almost non-existent in the Iberian systems. According to Sitzia et al (2017), the grain size gradients and the geochemical composition argue for a loess origin essentially related to aeolian abrasion of the sands in the south and a mixed origin (aeolian abrasion together with the contribution of alluvium from the Garonne) for the loess located on the right bank of the river.

\subsection{Other systems}

Other minor systems have developed in connection with rivers draining areas of high relief that were not or only slightly glaciated during the LGM. This is the case of the Saône valley, the Doubs valley and the upper Garonne basin in France, the upper Elbe basin in the Czech Republic and the Moravia River on the border between the Czech Republic and Slovakia. For the Moravian system, zircon morphology indicates a source from the Bohemian Massif (Morava alluvium) and Tertiary sedimentary rocks in the lower river (Lisá and Uher, 2006), while the geochemistry of the fine fraction also suggests a contribution from the NELB (Bosq et al., 2020b). Loess patches also occur in small intramontane basins in Italy and along the Adriatic coast (Slovenia to Albania). It should be noted that in Italy, the patches located at the foot of volcanoes around Rome and Naples likely correspond to weathered tephra and not to loess.

\subsection{Loess thickness}

The available loess thickness data are not evenly distributed across Europe and are much denser in France than elsewhere. Therefore, thickness variations are better represented in this country than in the rest of Europe. As the sections described in the literature are primarily used for chronostratigraphic studies and are among the thickest in a given region, the thicknesses indicated in most countries should be considered close to maxima. Keeping in mind this limitation, the map of total loess thickness shows the following points at the European scale (Fig. 9A):

(1) Extensive accumulations are associated with the perialpine systems, especially along the Rhine valley and the Danube valley, with thicknesses locally exceeding $30 \mathrm{~m}$. Many loess-palaeosol sequences (LPS) in the MDB (Hungary, Serbia) cover 800 ka to almost 1.1 Ma (e.g., Varga et al., 2011; Ujvari et al., 2014; Sümegi et al., 2018). The congruence of multiple aeolian systems in the MDB makes it a region of preferential loess deposition.

(2) The NELB is typified by comparatively thinner accumulations, ranging from 5 to $10 \mathrm{~m}$ except to the East (eastern Poland, up to $20 \mathrm{~m}$ ) and in the congruence area LRE-NELB. A westward decreasing 
trend is also clearly visible ( 3 to 4 m maximum in Brittany; Bigot and Monnier, 1987; Coutard et al., 2005). Only the last two to three glacial-interglacial cycles are usually preserved in the LPS in France and Germany (e.g., Coutard et al., 2018; Kels and Schirmer, 2010; Meijs, 2002), exceptionally the whole Middle and Upper Pleistocene (Antoine et al., 2020).

(3) In France, thin accumulations occur on the periphery of coastal (Aquitaine, Hernandez et al., 2012; Sitzia et al., 2017) and continental (Tours-Orléans region, Macaire, 1986; Gardère and Djemmali, 2018) systems. In Aquitaine, only the Weichselian and sometimes the Upper Saalian have given rise to substantial loess accumulations overlying a complex Middle Pleistocene palaeosol.

For France, the large network of observation points reveals a great variability in thickness within the NELB. The main factor involved is relief, with a preferential accumulation of loess in depressions on plateaus, on leeward slopes and at the foot of hills (Lautridou, 1985; Antoine, 2002). The loess cover is truly continuous only in northern France. In other regions, although large areas are characterised by a topsoil with a typical loess texture, the boreholes stored in the BSS indicate that the thickness is at best one metre and often unreported. Nevertheless, accumulations of several metres in thickness have been described in favourable locations.

In the Mediterranean areas, the extension of loess is reduced mainly due to relief and the lack of glacier-fed rivers, with the exception of the Rhône, Po and Durance. However, loess thickness can be substantial and exceed $10 \mathrm{~m}$ (Ebro valley, Boixadera et al., 2015; Tagus valley, Wolf et al., 2018). It can exceed $20 \mathrm{~m}$ in the Po valley (Washa et al., 2011) and along the Durance (Bonifay, 1962, 1965). Possible contribution from Saharan dust has been suggested by some authors (e.g., Mahowald et al., 2006), but remained minor compared to local inputs. In the Rhône valley, such Saharan contribution has not been detected by Bosq et al. (2020b) using geochemistry.

The map of loess thickness for the Last Glacial provides a less contrasting picture, with average accumulation of 3-6 $\mathrm{m}$ in many European regions (Fig. 9B). This pattern implies that the variation in total loess thickness is largely due to erosion processes and, to some extent, to differences in the age of the surfaces on which the loess accumulated (alluvial terraces, areas glaciated before the Weichselian). Areas of high deposition are located close to the coversands, (1) in the NELB with typically 8 to $14 \mathrm{~m}$ of loess in northern France, Belgium, Germany and Poland, with a clear decrease in France away from the sands, (2) in the URG, with peak deposition of up to $19 \mathrm{~m}$ at the edge of the graben (Nussloch; Antoine et al., 2009) where loess forms ridges ("gredas", Leger, 1990), and (3) in the MDB, with thicknesses reaching 15-20 m in Croatia and Serbia (Erdut, Galovic et al., 2009; Sarengrad, Galovic et al., 2011; Mosorin, Titel, Bockhorst et al., 2011, Markovic et al., 2015). Comparatively, the LDB is characterised by relatively weak accumulation ( 4 to $5 \mathrm{~m}$ ) whereas the total loess thickness can be considerable (> $30 \mathrm{~m}$; Jipa, 2014).

\subsection{Grain size and gradients}

The various aeolian systems are characterised by an almost regular change in grain size as a function of the distance from the coversands. The evolution of sand percentages from the LUCAS data is illustrated in Figure 10 for two profiles oriented perpendicular to the boundaries between coversand, sandy loess, and loess in Aquitaine and Belgium. Both profiles show a similar trend. The sand percentage adjusts on average to a negatively sloping line for the first $40 \mathrm{~km}$. The main divergence between regions is the decrease to a low asymptotic value, around $10-15 \%$ in the NELB, whereas it remains above $20-30 \%$ in other systems. 
The few data available on the main mode of loess measured by laser granulometry show a high degree of homogeneity in the NELB, with values ranging from 30 to $42 \mu \mathrm{m}$ (Fig. 11), down to $24 \mu \mathrm{m}$ at greater distances from the coversands (e.g., Courville section in the Paris Basin, Coussot et al., 2019). The section at Maastricht-Belvedere (Netherlands), located close to the sandy loess band, yields a mode around $47 \mu \mathrm{m}$ (J. Vandenberghe, written communication, 2021). A few samples from the Val de Saire along the French coast of the English Channel, also yield a mode at around $49 \mu \mathrm{m}$ (Coutard, 2003). Comparatively, as noted by Bosq et al. (2018), the main mode of loess taken from sections described elsewhere in Europe, in particular in southern and southeastern Europe, is far more variable and fluctuates between 30 and $75 \mu \mathrm{m}$.

In most regions, loess and sandy loess have a dominant grain size mode, which decreases with the distance from the coversands (Fig. 12). Depending on that value, the part of the distribution located beyond $63 \mu \mathrm{m}$ is of varying proportion and the decrease in sand percentage reflects the decrease in modal particle size. A few exceptions can be mentioned, such as Grafenberg 2, Germany (Fischer et al., 2019), where some samples are bimodal (one mode at $41 \mu \mathrm{m}$ distinct from the mode in the sands at $120 \mu \mathrm{m}$ ) (Fig. 12). The Aquitaine loess contrasts with other loess deposits due to a fine mode (14$20 \mu \mathrm{m}$ ), which decreases slightly away from the coversands. This results from the bimodal (or even plurimodal) nature of the grain size distribution, with a sand mode distinct from the silt mode (Sitzia et al., 2017). The trend as a function of distance is marked by the progressive increase in the amount of silt at the expense of sand, without a substantial change in the dominant silt mode. The loess of the Rhone valley has an intermediate grain size distribution between those of the NELB and Aquitaine, with a secondary silt mode of $\sim 15 \mu \mathrm{m}$ (Bosq et al., 2020a).

\section{Discussion}

The new map highlights distinct aeolian systems in Europe, the most extensive of which are related to particle sources of glacial origin transported by sandurs, particularly along the FIS, or by larger rivers (Manche, Rhine, Danube). Such observations have been made by previous investigators (e.g., Smalley, 1966; Tsoar and Pye, 1987; Muhs, 2013), although these have sometimes been questioned even by the same authors (Smalley et al., 2009). Nevertheless, these observations are in line with those made in current proglacial environments, which act as major dust sources (Bullard, 2013; Bullard and Austin, 2011). Overall, the measurements show that sediment production in current icecovered catchments (due to abrasion, quarrying and the remobilisation of previous sediments) is much higher, sometimes by an order of magnitude, than in unglaciated catchments (Hallet et al., 1996). Therefore, the extent of the loess belt primarily reflects the abundant production of silts by glacial action (Tsoar and Pye, 1987). Other mechanisms must have contributed to a lesser degree, particularly river transport (Osborne et al., 1993; Wright et al., 1998; Smith et al., 2002). However, the downstream decreasing trend of the thickness of Last Glacial loess along the Manche River and in the MDB-LDB clearly demonstrates that neither silt production during fluvial transport, nor inputs by tributaries from unglaciated regions were able to compensate for the decrease, by sedimentation and dilution, of the river's load of particles of glacial origin. It is likely that the large glacial lakes that occupied the North Sea (Patton et al., 2017) contributed to trapping suspended particles from meltwater, thus limiting the load carried downstream by the Manche River. The MDB, where inputs from glacial and local particle sources combined, is the largest area of loess accumulation in Europe (Markovic et al., 2015). 
The thickest loess deposits are related to the rivers draining the AIS and, therefore, suggest that the AIS contributed more to dust production than the FIS. Glacial abrasion occurs under temperatebased glaciers when ice slides over the bedrock. The abrasion rate depends primarily on ice velocity and, thus, on the slope of the bed, on ice thickness that modulates the stress applied to the bed, and on the nature of the rock substrate, particularly its hardness (e.g., de Winter et al., 2012). These factors may have acted together to explain the high silt production by the AIS, particularly the steep slope of valley glaciers and the relatively soft bedrock (predominantly sedimentary rocks), in contrast to the plutonic and metamorphic basement of the Scandinavian Shield.

In the NESB-NELB system, the zoning of coversand-sandy loess-loess is well marked and mainly controlled by relief. In the loess belt, the texture of the sand-silt fraction is approximately unimodal and the mode decreases gradually with the distance from the boundary of the coversands. Some samples from the Grafenberg section (Germany), located in the sandy loess band, are exceptions and are bimodal. Given the context, they can be interpreted as the result of a mixture (by bioturbation or cryoturbation) of silty and sandy beds, linked to variations in wind strength or soil moisture. These deposits may be a finer equivalent of the facies composed of alternating sand and silt beds described by Schwan (1986) and Kasse (2002) in the coversands of Belgium and the Netherlands.

This pattern is in striking contrast to the coastal (southwest France, Iberian Peninsula) and continental (Ebro, Duero and Loire basins, Nuremberg region) aeolian systems, where the loess belt is much less extensive or even almost absent. Total deposition was minimal ( 1 to $2 \mathrm{~m}$ ) during the Last Glacial period in Aquitaine and in the Loire basin (Hernandez et al., 2012; Gardère and Djemmali, 2018). The silty fraction comes both from the reworking of older sediments and from the abrasion of sand grains during aeolian transport, especially in coastal systems.

According to experiments (Kuenen, 1960; Wright et al., 1998; Bullard et al., 2007), aeolian abrasion is a process capable of producing silt-sized particles in significant quantities, although comparatively small compared to fluvial and particularly glacial abrasion, with often a fine mode $(<20 \mathrm{~m})$ (Wright et al., 1998; Smith et al., 2002; Bullard et al., 2007). Swet et al. (2020) suggest, however, that fragmentation of quartz sand produces little dust, most of the particles released during collisions coming from the erosion of clay coatings. The emission of dust caused by the blasting of fine-grained soils by saltating grains (Shao, 2001) may also have contributed greatly to the genesis of loess, especially during the phases of coversand extension. The bimodal particle size distribution of Aquitaine loess and sandy loess (Sitzia et al., 2017) is unusual compared to their equivalents derived from glacial sources. This is likely the result of silt production by aeolian abrasion, as grain size gradients and geochemistry indicate a single source, the coversands. It can be noted here that Negev loess, which is derived in part from the Sinai dune sands by abrasion (together with a contribution of African clay-rich dust, e.g., Wieder et al., 2008), also has a bimodal distribution with a mode shifted towards fine silt $(4-10 \mu \mathrm{m})$ (Crouvi et al., 2008).

The amount of fines produced by this process is a function of the duration of grain transport in saltation and the distance travelled. This factor may explain why loess is relatively well developed in Aquitaine, but is almost absent in Iberian systems. In Aquitaine, the $-120 \mathrm{~m}$ isobath (i.e. the level reached during the LGM lowstand) is located 100 to $160 \mathrm{~km}$ to the west of the limit of the maximal coversand extension, or even significantly more (>200 km) considering that the dominant winds came from the northwest (Sitzia et al., 2017). Conversely, it is located less than $50 \mathrm{~km}$ away in the 
Iberian Peninsula, both because of the narrowness of the continental shelf and the small extent of the aeolian sands due to relief.

One of the most intriguing points that emerges from the grain size of the samples listed in the database is the very homogeneous nature of the NELB loess compared to other regions. The particle size distribution shows a mode falling within a narrow window, ranging from 47 to $30 \mu \mathrm{m}$, while it ranges from 30 to $75 \mu \mathrm{m}$ elsewhere. In addition, coversands, sandy loess and loess form well-defined bands in the NELB, whereas this pattern is more complex in the other systems, with the exception of the Aquitaine. In particular, the coversands are poorly developed compared to the other categories of aeolian deposits in the LDB, the Po and the Rhône valleys, whereas the sandy loess deposits cover large areas. Two factors can be considered to account for this pattern, (1) the grain size gradient from the sources to the distal zones, (2) the influence of vegetation on particle trapping.

The distance of the sections from the sources and the gradient due to particle sorting during transport, modulated by the effects of relief, is often the main factor invoked to explain the grain size variations. This effect is real and accounts for the formation of bands of increasingly fine texture away from the sources. Fluctuations are also observed within each LPS and are thought to reflect variations in wind speed and precipitation regime in relation to climatic fluctuations (e.g., Rousseau et al., 2002, 2011; see Ujvari et al., 2016, for a critical assessment of this proxy). However, the distance-from-source factor does not provide an adequate explanation for why the sections described in the NELB have similar grain sizes in contrast to other regions, unless one assumes that geomorphologists have only documented one particular type of loess in the NELB.

The influence of vegetation has been proposed as a co-factor behind the variability of grain size by Bosq et al. (2018) based on observations made in the Rhône valley. The effectiveness of trapping windblown particles by vegetation has long been recognised (e.g., Tsoar and Pye, 1987; Pye, 1995) and has been the subject of numerous field experiments and measurements (e.g., Raupach et al., 2001; Leenders et al., 2007; Field et al., 2012; Hugenholtz and Wolfe, 2010; Youssef et al., 2012; Suter-Burri et al., 2013). This work shows that vegetation favours the deposition of particles by reducing wind speed and by intercepting particles on leaves and stems. Its influence largely depends on plant size, arrangement and density, which determine the quantity of particles retained relative to the flow. Overall, bush, shrub or tree vegetation acts as a much more effective particle trap than grass and a fortiori cryptogamic vegetation, and favours sedimentation at its base. Simultaneous capture of sand in saltation or in modified saltation and of silt in suspension by tall vegetation, as well as wind speed reduction at ground level, which limits the erosion by the impact of saltating grains of the particles already deposited, help to explain the formation of sandy loess near the sources. In the Rhône valley, the thickest accumulations, which are most likely to provide a detailed chronostratigraphic record, are all characterised by a coarse texture (sandy loess), whereas the distal fine loess forms only poorly developed accumulations (Bosq et al., 2018, 2020a).

Various arguments suggest that the scheme proposed for the Rhône valley can be extended to other regions and that the vegetation factor can account for some particularities of loess at the European scale. As in today's cold and temperate environments, a latitudinal gradient of vegetation must have existed in Europe during the glacial periods. The NESB was associated with a periglacial desert landscape (Kasse, 2002), while denser vegetation developed towards the south. Simulations (Strandberg et al., 2011; Janská et al., 2017) as well as reconstructions based on pollen records (Cheddadi and Bar-Hen, 2009; Magyari et al., 2014) agree on the predominance of steppe or tundra 
steppe over large parts of Europe, while shrubby steppe existed in the south (Iberian and Italic peninsulas, Balkans, southern France). Low $\mathrm{CO}_{2}$ concentration in the atmosphere and the increase in wind speed hampered the development of trees (Woillez et al., 2011), which persisted locally as open stands in favourable sites, especially in mountainous areas and valleys (Magyari et al., 2014). Genetic data (Petit et al., 2002; Cheddadi et al., 2006; Magri et al., 2006) and simulations (Svenning et al., 2008) also indicate the persistence of LGM refugia in large parts of Europe for boreal forest species and in southern Europe for mesophilic trees. Therefore, it seems likely that the vegetation gradient had a significant impact on loess sedimentation.

The depositional models proposed by Bosq et al. (2018) modified from Pye (1995), which involve vegetation, accurately capture some specific features of the different aeolian systems in Europe. In northern Europe, typified by a virtual absence of vegetation (NESB) or cryptogams (Smalley et al., 2011; Svirčev et al., 2019) and open steppe (NELB), vegetation interfered little with particle transport. The progression of sand by saltation was limited by relief (Mason et al., 1999) and the sorting of suspended dust led to the formation of well-defined bands of sandy loess and loess. In these bands, the accumulation rate decreased progressively with the distance to the sources. The sections described in the loess band are thus characterised by a homogeneous texture with a reduced sand component. In southern Europe, on the other hand, tall vegetation (shrubby steppe) interfered strongly with the transport of particles. Sand spreading was limited by vegetation and the extent of the coversand band was reduced. The simultaneous capture of sand and dust favoured the formation of thick sandy loess deposits near the sources. The sedimentation rate was, therefore, very high in this band and then rapidly decreased at greater distance. In the other regions of Europe (URG, UDB, MDB, Moravia), intermediate situations existed in relation to steppe-tundra vegetation.

\section{Conclusions}

The main conclusions that can be drawn from this study are the following:

(1) The improvement of the extraction procedure of aeolian deposits from the LUCAS topsoil texture database compared to Bertran et al. (2016) allowed generation of a map that agrees reasonably well with those based on a classical geological approach. This method has the advantage of providing a map of equal precision for all the regions and of clearly showing grain size gradients.

(2) The map shows three main types of aeolian systems, i.e. systems associated with ice sheets (FIS, BIIS, AIS) and the rivers they feed, continental systems related to the erosion of sedimentary rocks, and coastal systems. Some have a mixed character (e.g., Middle Danube). All systems are relatively independent of each other.

(3) Each system combines a band of coversands of varying extent close to the sources with bands of sandy loess and loess away from the sources. This pattern is well developed in northern Europe (North European Sand Belt and Loess Belt). In southern Europe, on the other hand, coversands are poorly developed along the rivers, whereas sandy loess was deposited over large areas. Loess is mainly present in systems derived from glacial sources and suggests that glacial abrasion was the main factor that provided fine particles to aeolian entrainment and transport.

(4) The total thickness of loess is highly variable throughout Europe, for reasons related to the sedimentation rate, the age of the surfaces on which the loess was deposited, and erosion processes. The areas of greatest accumulation are associated with the rivers draining the AIS (Rhine, Danube, 
Rhône). The Middle Danube, which combines sources of glacial origin (AIS) and local sources (erosion of sedimentary rocks outcropping in the Pannonian Basin due to wind channeling by the relief), constitutes the main accumulation area in Europe. Conversely, continental and coastal systems generated only limited loess cover.

(5) The thickness of loess from only the Last Glacial period is more homogeneous. The main factor involved in thickness variations is the proximity to the sources. The downstream decrease in thickness along rivers draining the ice sheets (Manche River, Danube) shows that local inputs along their course do not compensate for the decrease in glacial particles due to sedimentation and dilution.

(6) The latitudinal gradient of vegetation probably played an important role in loess sedimentation during the LGM. Weak interference between particle transport and vegetation (periglacial desert in the NESB, cryptogamic crusts and steppe in the NELB) allowed for particle sorting through aeolian transport to develop. The loess band is extensive in low relief areas and is typified by low sand content. In southern Europe, on the other hand, the capture of saltating and suspended particles by the shrubby steppe vegetation led to the dominant accumulation of sandy loess near sources.

These findings open up new perspectives in the study of aeolian dynamics during glacial periods. The close connection between glacial sources and loess suggests that:

(1) The chronology of deposition may not be perfectly synchronous at the European scale, insofar as the growth and retreat of the ice sheets did not take place strictly synchronously and the palaeogeographic changes caused by the retreat necessarily led to the displacement of sources, particularly in the case of the FIS. In addition, non-glacially-fed systems (coastal and continental systems) probably behaved differently, since the factors controlling the susceptibility of soils to deflation are not identical to those controlling glacial dynamics.

(2) Simulations of LGM dust emission, which only take into account the susceptibility of soils to deflation as a function of moisture, vegetation cover and wind speed (Sima et al., 2013; Hopcroft et al., 2015; Schaeffernicht et al., 2020), are probably not suitable for reproducing the production of dust, most of which came from the alluvium of glacier-fed rivers.

\section{Acknowledgements}

We would like to thank all those who provided us with particle size data, P. Antoine (CNRS, Meudon), J. Bösken (University of Aachen), P. Fischer (Johannes Gutenberg-University Mainz), K. Flašarova (Charles University, Prague), Z. Jary (University of Wroclaw), S. Meszner (University of Dresden), P. Mroczek, (Maria Curie-Sklodowska University, Lublin), J. Vandenberghe (University of Amsterdam). We also benefited from discussions with M.F. Sanchez-Goñi (University of Bordeaux) about the LGM vegetation. The two anonymous reviewers are also acknowledged for their suggestions to improve the original manuscript.

\section{Supplementary Information}

Map of European eolian deposits (shapefiles)

Table of loess observation points (Excel file)

\section{References}


621 Ambert, P., 2013. Formes et formations périglaciaires du Pléistocène supérieur dans le Midi 622 méditerranéen français : I'exemple de l’Étang de Berre. Quaternaire 24(3), 293-301.

623 Antoine, P., 2002. Les lœss en France et dans le Nord-Ouest européen. Revue Française de 624 Géotechnique 99, 3-21.

625 Antoine, P., Rousseau, D.D., Moine, O., Kunesch, S., Hatté, C., Lang, A., Tissoux, H., Zöller, L., 2009.

626 Rapid and cyclic aeolian deposition during the Last Glacial in European loess: a high-resolution record 627 from Nussloch, Germany. Quaternary Science Reviews 28, 2955-2973.

628 Antoine, P., Bahain, J.J., Coutard, S., Limondin-Lozouet, N., 2020. La séquence de Grâce-Autoroute 629 (Somme, France) : une référence pour l'enregistrement des variations climatiques quaternaires 630 depuis 1 Ma à l'ouest de l'Europe. Quaternaire 31(3), 205-230.

631 Badura, J., Jary, Z., Smalley, I., 2013. Sources of loess material for deposits in Poland and parts of

632 Central Europe: The lost Big River. Quaternary International 296, 15-22.

633 Ballabio, C., Panagos, P., Monatanarella, L., 2016: Mapping topsoil physical properties at European 634 scale using the LUCAS database. Geoderma 261, 110-123.

635 Bateman, M.D., 1995. Thermoluminescence dating of the British coversand deposits. Quaternary 636 Science reviews 14, 191-198.

637 Bateman, M.D., Dıéz-Herrero, A., 2001. The timing and relation of Aeolian sand deposition in central 638 Spain to the aeolian sand record of NW Europe. Quaternary Science Reviews 20, 779-782.

639 Bernat-Rebollal M.B., Pérez-González A., 2008. Inland aeolian deposits of the Iberian Peninsula: Sand 640 dunes and clay dunes of the Duero Basin and the Manchega Plain. Palaeoclimatic considerations.

641 Geomorphology 102, 207-220.

642 Bertran, P., Andrieux, E., Bateman, M.D., Fuchs, M., Klinge, M., Marembert, F., 2020. Mapping and

643 chronology of coversands and dunes from the Aquitaine basin, southwest France. Aeolian Research

644 47, 100628 (https://doi.org/10.1016/j.aeolia.2020.100628).

645 Bertran, P., Liard, M., Sitzia, L., Tissoux, H., 2016. A map of Pleistocene aeolian deposits in Western

646 Europe, with special emphasis on France. Journal of Quaternary Science 31 (8), 844-856.

647 Bertran, P., Bateman, M.D., Hernandez, M., Mercier, N., Millet, D., Tastet, J.P., 2011. Inland aeolian

648 deposits of southwest France: facies, stratigraphy and chronology. Journal of Quaternary Science 26

649 (4), 374-388.

650 Bigot B., Monnier, J.L., 1987. Stratigraphie et sédimentologie des lœss récents du nord de la

651 Bretagne. Données nouvelles d'après l'étude des coupes des Sables-d'Or-Les-Pins et de Port Lazo

652 (Côtes-du-Nord, France). Bulletin de l'Association Française pour l'Etude du Quaternaire 1, 27-36.

653 Bokhorst, M.P., Vandenberghe, J., Sümegi, P., Łanczont, M., Gerasimenko, N.P., Matviishina, Z.N., 654 Marković, S.B., Frechen, M., 2011. Atmospheric circulation patterns in central and eastern Europe 655 during the Weichselian Pleniglacial inferred from loess grain-size records. Quaternary International $656234,62-74$.

657 Boixadera, J., Poch, R.M., Lowick, S.E., Balasch, J.C., 2015. Loess and soils in the eastern Ebro Basin.

658 Quaternary International 376, 114-133. 
Bonifay, E., 1962. Les terrains quaternaires dans le sud-est de la France. Mémoire de l'Institut de Préhistoire, University of Bordeaux, 194 pp.

Bonifay, E., 1965. Stratigraphie des lœss anciens et récents dans le sud-est de la France. Bulletin de I'Association Française pour l'Étude du Quaternaire 2, 21-34.

Borderie, Q., Chamaux, G., Roussaffa, H., Douard, M., Fencke, E., Rodot, M.A., Perrichon, P., Selles, H., 2017. La couverture lœssique d’Eure-et-Loir (France) : Potentiel pédo-sédimentaire et organisation spatiale. Quaternaire 28(3), 389-400.

Bosq, M., Kreutzer, S., Bertran, P., Degeai, J.P., Dugas, P., Kadereit, A., Lanos, P., Moine, O., Paffner, N., Queffelec, A., Sauer, D., 2020a. Chronostratigraphy of two Late Pleistocene loess-palaeosol sequences in the Rhône Valley (southeast France). Quaternary Science Reviews 245, 106473 (https://doi.org/10.1016/j.quascirev.2020.106473).

Bosq, M., Bertran, P., Degeai, S.P., Queffelec, A., Moine, O., 2020b. Geochemical signature of sources, recycling and weathering in the Last Glacial loess from the Rhône Valley (southeast France) and comparison with other European regions. Aeolian Research 42, 100561 (https://doi.org/10.1016/j.aeolia.2019.100561).

Bosq, M., Bertran, P., Degeai, J.P., Kreutzer, S., Queffelec, A., Moine, O., Morin, E., 2018. Last Glacial aeolian landforms and deposits in the Rhône Valley (SE France): spatial distribution and grain-size characterization. Geomorphology 318, 250-269.

Buggle, B., Glasera, B., Zöller, L., Hambach, U., Marković, S., Glaser, I., Gerasimenko, N., 2008. Geochemical characterization and origin of Southeastern and Eastern European loesses (Serbia, Romania, Ukraine). Quaternary Science Reviews 27, 1058-1075.

Bullard, J.E., 2013. Contemporary glacigenic inputs to the dust cycle. Earth Surface Processes and Landforms 38, 71-89.

Bullard, J.E., Austin, M.J., 2011. Dust generation on a proglacial floodplain, West Greenland. Aeolian Research 3, 43-54.

Bullard, J.E., Mctainsh, G.H., Pudmenzky, C., 2007. Factors affecting the nature and rate of dust production from natural dune sands. Sedimentology 54, 169-182.

Catt, J.A., 1977. Loess and coversand. In: Shotton, F.W., (ed.), British Quaternary Studies - Recent Advances. Clarendon Press, Oxford, pp. 221-229.

Catt, J.A., 1985. Soil particle size distribution and mineralogy as indicators of pedogenic and geomorphic history: examples from the loessial soils of England and Wales., in: Richard K.S., Arnet R.R., Ellis S. (Eds): Geomorphology and Soils. G. Allen \& Unwin, London, pp. 202-218.

Cheddadi, R., Vendramin, G.G., Litt, T., Francois, L., Kageyama, M., Lorentz, S., Laurent, J.-M., de Beaulieu, J.-L., Sadori, L., Jost, A., Lunt, D., 2006. Imprints of glacial refugia in the modern genetic diversity of Pinus sylvestris. Global Ecology and Biogeography 15, 271-282.

Cheddadi, R., Bar-Hen, A., 2009. Spatial gradient of temperature and potential vegetation feedback across Europe during the late Quaternary. Climate Dynamics 32, 371-379. 
Chen, S., Richer-de-Forges, A.C., Mulder, V.L., Martelet, G., Loiseau, T., Lehmann, S., Arrouays, D., 2020. Digital mapping of the soil thickness of loess deposits over a calcareous bedrock in central France. Catena 198, 105062 (https://doi.org/10.1016/j.catena.2020.105062).

Clark, C.D., Hughes, A.L.C., Greenwood, S.L., Jordan, C., Sejrup, H.P., 2012. Pattern and timing of retreat of the last British-Irish Ice Sheet. Quaternary Science Reviews 44, 112-146.

Cremaschi, M., Zerboni, A., Nicosia, C., Negrino, F., Rodnight, H., Spölt, C., 2015. Age, soil-forming processes, and archaeology of the loess deposits at the Apennine margin of the Po plain (northern Italy): New insights from the Ghiardo area. Quaternary International 376, 173-188.

Crouvi, O., Amit, R., Enzel, Y., Porat, N., Sandler, A., 2008. Sand dunes as a major proximal dust source for late Pleistocene loess in the Negev Desert, Israel. Quaternary Research 70, 275-282.

Coussot, C., Liard, M., Kreutzer, S., Mercier, N., 2019. Séquence de comblement d'un paléovallon en contexte de plateau beauceron (290-10 ka) : la coupe de Courville- sur- Eure (Eure- et- Loir, France). Quaternaire 30(2), 167-183.

Coutard, S., 2003. Formations quaternaires en bordure d'une mer épicontinentale, la Manche. Tectonique, eustatisme, climat et occupations humaines. Exemple du Val de Saire (Normandie, France). Thèse de Doctorat en géologie, University of Caen.

Coutard, S., Lautridou, J.P., Rhodes, E., 2005. Discontinuités dans l'enregistrement des cycles interglaciaire-glaciaire sur un littoral en contexte intraplaque. Exemple du Val de Saire (Normandie, France). Quaternaire 16(3), 217-227.

Coutard, S., Antoine, P., Hérisson, D., Pirson, S., Balescu, S., Forget-Brisson, L., Spagna, P., Debenham, N., Barré, M., Chantreau, Y., Giros, R., Lamothe, M., 2018. La séquence lœssique Pléistocène moyen à supérieur d'Etricourt-Manancourt (Picardie, France) : un enregistrement pédo- sédimentaire de référence pour les derniers 350 ka. Quaternaire 29(4), 311-346.

Coutard, S., Font, C., Locht, J.L., Deschodt, L., Goval, E., Kiefer, D., Sellier, N., Swinnen, C., Mariette, E., Hébert, S., Paris, C., Hérisson, D., unpublished. Base de données et SIG sur les séquences pléistocènes en France septentrionale. Inrap Nord-Picardie, Amiens.

De Winter, I.L., Storms, J.E.A., Overeem, I., 2012. Numerical modeling of glacial sediment production and transport during deglaciation. Geomorphology 167-168, 102-114.

Ehlers, J., Gibbard, P.L., 2004. Quaternary Glaciations-Extent and Chronology: part I: Europe. Elsevier, Amsterdam.

Field, J.P., Breshears, D.D., Whicker, J.J., Zou, C.B., 2012. Sediment capture by vegetation patches: Implications for desertification and increased resource redistribution. Journal of Geophysical Research 117, G01033 (https://doi.org/10.1029/2011JG001663).

Fischer, P., Hambach, U., Klasen, N., Schulte, P., Zeeden, C., Steininger, F., Lehmkuhl, F., Gerlach, R., Radtke, U., 2019. Landscape instability at the end of MIS 3 in western Central Europe: evidence from a multi proxy study on a Loess-Palaeosol-Sequence from the eastern Lower Rhine Embayment, Germany. Quaternary International 502, 119-136. 
Font, C., Coutard, S., Paris, C., Hérisson, D., Goval, E., Locht, J.L., 2016. Formations superficielles et occupations paléolithiques en France septentrionale : Développement et premières applications d'un Système d'Information Géographique (SIG). Revue Archéologique de Picardie 1-2, 41-68.

Gabert, J., 1965. Phénomènes périglaciaires du Quaternaire supérieur et néotectonique dans la région de l'Étang de Berre (Basse-Provence occidentale). $90^{\text {òme }}$ Congrès des Sociétés Savantes, Nice, $2,75-88$.

Galović, L., Frechen, M., Halamić, J., Durn, G., Romic, M., 2009. Loess chronostratigraphy in Eastern Croatia-A luminescence dating approach. Quaternary International 198, 85-97.

Galović, L., Frechen, M., Peh, Z., Durn, G., Halamić, J., 2011. Loess/palaeosol section in Sarengrad, Croatia - A qualitative discussion on the correlation of the geochemical and magnetic susceptibility data. Quaternary International 240, 22-34.

Gardère, P., Djemmali, N., 2018. Découpage séquentiel et nouvelles données archéologiques des Limons des plateaux au nord de Tours (Indre-et-Loire). Revue archéologique du Centre de la France 57, 1-23 (https ://journals.openedition.org/racf/2761).

Granja, H.M., de Groot, T.A.M., Costa, A.L., 2008. Evidence for Pleistocene wet aeolian dune and interdune accumulation, S. Pedro da Maceda, north-west Portugal. Sedimentology 55, 1203-1226.

Gutiérrez-Elorza, M., Desir, G., Gutiérrez-Santolalla, F., 2002. Yardangs in the semiarid central sector of the Ebro Depression (NE Spain). Geomorphology 44, 155-170.

Haase, D., Fink, J., Haase, G., Ruske, R., Pécsi, M., Richter, H., Altermann, M., Jäger, K.D., 2007. Loess in Europe-its spatial distribution based on a European Loess Map, scale 1:2,500,000. Quaternary Science Reviews 26, 1301-1312.

Hallet, B., Hunter, L., Bogen, J., 1996. Rates of erosion and sediment evacuation by glaciers: A review of field data and their implications. Global and Planetary Change 12, 213-235.

Hernandez, M., Mercier, N., Bertran, P., Colonge, D., Lelouvier, L.A., 2012. Premiers éléments de datation des industries du Pléistocène moyen (Acheuléen - paléolithique moyen ancien) de la région pyrénéo-garonnaise : une approche géochronologique pluri-méthodes (TL, OSL et TT-OSL) des sites de Duclos et Romentères. Paléo 23, 155-170.

Hopcroft, P.O., Valdes, P.J., Woodward, S., Joshi, M.M., 2015. Last glacial maximum radiative forcing from mineral dust aerosols in an Earth system model. Journal of Geophysical Research: Atmospheres $120,8186-8205$.

Hugenholtz, C.H., Wolfe, S.A., 2010. Rates and environmental controls of aeolian dust accumulation, Athabasca River Valley, Canadian Rocky Mountains. Geomorphology 121, 274-282.

Hughes, A.L.C., Gyllencreutz, Lohne, Ø.S., Mangerud, J., Svendsen, J.I., 2016. The last Eurasian ice sheets - a chronological database and time-slice reconstruction, DATED-1. Boreas 45, 1-45.

Janská, V., Jiménez-Alfaro, B., Chytrý, M., Divišek, J., Anenkhonov, O., Korolyuk, A., Lashchinskyi, N., Culek, M., 2017. Palaeodistribution modelling of European vegetation types at the Last Glacial Maximum using modern analogues from Siberia: Prospects and limitations. Quaternary Science Reviews 159, 103-115. 
771 Jipa, D.C., 2014. The conceptual sedimentary model of the Lower Danube loess basin:

772 Sedimentogenetic implications. Quaternary International 351, 14-24.

773 Kasse, C., 1997. Cold-Climate Aeolian Sand-Sheet Formation in north-western Europe (c. 14-12.4 ka);

774 a Response to Permafrost Degradation and Increased Aridity. Permafrost and Periglacial Processes 8 , 775 295-311.

Kasse C., 2002. Sandy aeolian deposits and environments and their relation to climate during the Last

777 Glacial Maximum and Lateglacial in northwest and central Europe. Progress in Physical Geography 26

778 (4), 507-532.

779 Kels, H., Schirmer, W., 2010. Relation of loess units and prehistoric find density in the Garzweiler 780 open-cast mine, Lower Rhine. E\&G Quaternary Science Journal 59 (1-2), 59-65.

781 Koster, E.A., 1988. Ancient and modern cold-climate aeolian sand deposition: a review. Journal of 782 Quaternary Science 3, 69-83.

783 Koster, E.A., 2005. Recent Advances in Luminescence Dating of Late Pleistocene (Cold-Climate)

784 Aeolian Sand and Loess Deposits in Western Europe. Permafrost and Periglacial Processes 16, 131-

785143.

786 Kuenen, P.H., 1960. Experimental abrasion 4: eolian action. Journal of Geology 68, 427-449.

787 Lautridou J.P., 1985. Le cycle périglaciaire pléistocène en Europe du nord-ouest et plus

788 particulièrement en Normandie. Thèse d'état, University of Caen, 908 pp.

789 Leenders, J.K., van Boxel, J.H., Sterk, G., 2007. The Effect of Single Vegetation Elements on Wind

790 Speed and Sediment Transport in the Sahelian Zone of Burkina Faso. Earth Surface Processes

791 Landforms 32, 1454-1474.

792 Leger, M., 1990. Loess landforms. Quaternary International 7/8, 53-61.

793 Lehmkuhl, F., Zens, J., Krauß, L., Schulte, P., Kels, H., 2016. Loess-paleosol sequences at the northern

794 European loess belt in Germany: Distribution, geomorphology and stratigraphy. Quaternary Science

795 Reviews 153, 11-30.

796 Lehmkuhl, F., Pötter, S., Pauligk, A., Bösken, J., 2018a. Loess and other quaternary sediments in

797 Germany. Journal of Maps, 14(2), 330-340.

798 Lehmkuhl, F., Bösken, J., Hošek, J., Sprafke, T., Marković, S.B., Obreht, I., Hambach, U., Sümegi, P., 799 Thiemann, A., Steffens, S., Lindner, H., Veres, D. Zeeden, C., 2018b. Loess distribution and related 800 Quaternary sediments in the Carpathian Basin. Journal of Maps, 14(2), 673-682.

801 Lehmkuhl, F., Nett, J.J., Pötter, S., Schulte, P., Sprafke, T., Jary, Z., Antoine, P., Wacha, L., Wolf, D.,

802 Zerboni, A., Hošek, J., Marković, S.B., Obreht, I. , Sümegi, P, Veres, D., Zeeden, C., Boemke, B.,

803 Schaubert, V., Viehweger, J., Hambach, U., 2021. Loess landscapes of Europe - Mapping,

804 geomorphology, and zonal differentiation. Earth-Science Reviews,

805 https://doi.org/10.1016/j.earscirev.2020.103496.

806 Liard, M., Tissoux, H., Deschamps, S., 2017. Les alluvions anciennes de la Loire en orléanais (France, 807 Loiret), une relecture à l'aune de travaux d'archéologie préventive et d'un programme de datations 808 ESR. Quaternaire 28(1), 105-128. 
809 Lindner, H., Lehmkuhl, F., Zeeden, C., 2017. Spatial loess distribution in the eastern Carpathian Basin:

810 a novel approach based on geoscientific maps and data. Journal of Maps 13, 173-181.

811 Lisá, L., Uher, P., 2006. Provenance of Würmian loess and loess-like sediments of Moravia and Silesia

812 (Czech Republic): a study of zircon typology and cathodoluminescence. Geologica Carpathica 57(5),

813 397-403.

814 Macaire J.J., 1986. Apport de l'altération superficielle à la stratigraphie - exemple des formations

815 alluviales et éoliennes plio-quaternaires de Touraine (France). Bulletin de l'Association Française pour

816 l’Etude du Quaternaire 3/4, 233-245.

817 Magri, D., Vendramin, G.G., Comps, B., Dupanloup, I., Geburek, T., Gömöry, D., Latalowa, M., Litt, T.,

818 Paule, L., Roure, J.M., Tantau, I., van der Knaap, W.O., Petit, R.J., de Beaulieu, J.L., 2006. A new

819 scenario for the Quaternary history of European beech populations: palaeobotanical evidence and

820 genetic consequences. New Physiologist 171, 199-221 (https://doi.org/10.1111/j.1469-

$8218137.2006 .01740 . x)$

822 Magyari, E.K., Kuneš, P., Jakab, G., Sümegi, P., Pelánková, B., Schäbitz, F., Braun, M., Chytrý, M., 2014.

823 Late Pleniglacial vegetation in eastern-central Europe: are there modern analogues in Siberia?

824 Quaternary Science Reviews 95, 60-79.

825 Mahowald, N. M., Muhs, D. R., Levis, S., Rasch, P. J., Yoshioka, M., Zender, C. S., Luo, C., 2006. Change

826 in atmospheric mineral aerosols in response to climate: Last glacial period, preindustrial, modern,

827 and doubled carbon dioxide climates. Journal of Geophysical Research: Atmospheres, 111 (D10).

828 Marković, S.B., Stevens, T., Kukla, G.J., Hambach, U., Fitzsimmons, K.E., Gibbard, P., Buggle, B., Zech, 829 M., Guo, Z., Hao, Q., Wu, H., O’Hara Dhand, K., Smalley, I.J., Újvári, G., Sümegi, P., Timar-Gabor, A.,

830 Veres, D., Sirocko, F., Vasiljević, D.A., Jary, Z., Svensson, A., Jović, V., Lehmkuhl, F., Kovács, J., Svirčev,

831 Z., 2015. Danube loess stratigraphy - Towards a pan-European loess stratigraphic model. Earth-

832 Science Reviews 148, 228-258.

833 Marks, L., 2002. Last Glacial Maximum in Poland. Quaternary Science Reviews 21, 103-110.

834 Mason, J.A., Nater, E.A., Zanner, W., Bell, J.C., 1999. A new model of topographic effects on the

835 distribution of loess. Geomorphology 28, 223-236.

836 Meijs, E.P.M., 2002. Loess stratigraphy in Dutch and Belgian Limburg. Eiszeitalter und Gegenwart

$837131,114-130$.

838 Muhs, D.R., 2013. The geologic records of dust in the Quaternary. Aeolian Research 9, 3-48.

839 Murton, J.A., Whiteman, C.A., Allen, P., 1995. Involutions in the Middle Pleistocene (Anglian) Barham

840 Soil, eastern England: a comparison with thermokarst involutions from arctic Canada. Boreas 24, 269-

841280.

842 Murton, J.B., Bateman, M.D., Baker, C.A., Knox, R., Whiteman, C.A., 2003. The Devensian periglacial

843 record on Thanet, Kent, UK. Permafrost and Periglacial Processes 14, 217-246.

844 Osborne, R.H., Bomer III, E.J., Wang, Y.C., Lu, Y., 1993. Application of a tumbler experiment using

845 granodioritic grus to examine the character of quartz-grain fracture in high-gradient streams.

846 Geological Society of America Special Paper 284, 211-234. 
Patton, H., Hubbard, A., Andreasen, K., Auriac, A., Whitehouse, P.L., Stroevent, A.P., Shackleton, C., Winsborow, M., Heyman, J., Hall, A.M., 2017. Deglaciation of the Eurasian ice sheet complex. Quaternary Science Reviews 169, 148-172.

Petit, R.J., Brewer, S., Bordács, S., Burg, K., Cheddadi, R., Coart, E., Cottrell, J., Csaikl, U.M., van Dam, B., Deans, J.D., Espinel, S., Fineschi, S., Finkeldey, R., Glaz, I., Goicoechea, P.G., Svejgaard Jensen, J., König, A.O., Lowe, A.J., Flemming Madsen, S., Mátyás, G., Munro, R.C., Popescu, F., Slade, D., Tabbener, H., de Vries, S.G.M., Ziegenhagen, B., de Beaulieu, J.L., Kremer, A., 2002. Identification of refugia and post-glacial colonisation routes of European white oaks based on chloroplast DNA and fossil pollen evidence. Forest Ecology and Management 156, 49-74.

Prognon, F., Lacquement, F., Ricordel-Prognon, C., Quesnel, F., Nehlig, P., Courbouleix, S., Quinquis, J.P., Martin, P., Ramsbourg, D., Lebret, P., 2011. Regolith map of France. Quaternaire 22 (4), 357-362.

Pye, K., 1995. The nature, origin and accumulation of loess. Quaternary Science Reviews 14, 653-667.

Raupach, M.R., Woods, N., Dorr, G., Leys, J.F., Cleugh, H.A., 2001. The entrapment of particles by windbreaks. Atmospheric Environment 35, 3373-3383.

Rousseau, D.D., Antoine, P., Hatté, C., Lange, A., Zöller, L., Fontugne, M., Ben Othman, D., Luck, J.M., Moine, O., Labonne, M., Bentaleb, I., Jolly, D., 2002. Abrupt millennial climatic changes from Nussloch (Germany) Upper Weichselian eolian records during the Last Glaciation. Quaternary Science Reviews 21(14-15), 1577-1582.

Rousseau, D.D., Antoine, P., Gerasimenko, N., Sima, A., Fuchs, M., Hatte, C., Moine, O., Zöller, L., 2011. North Atlantic abrupt climatic events of the last glacial period recorded in Ukrainian loess deposits, Climate of the Past 7(1), 221-234 (https://doi.org/10.5194/cp-7-221-2011).

Schatz, A.K., Qi, Y., Siebel, W., Wu, J., Zöller, L., 2015. Tracking potential source areas of Central European loess: examples from Tokaj (HU), Nussloch (D) and Grub (AT). Open Geoscience 7, 678-720 (https://doi.org/10.1515/geo-2015-0048).

Schaffernicht, E.J., Ludwig, P., Shao, Y., 2020. Linkage between dust cycle and loess of the Last Glacial Maximum in Europe. Atmospheric Chemistry and Physics 20, 4969-4986.

Schwan, J., 1986. The origin of horizontal alternating bedding in weichselian Aeolian sands in Northwestern Europe. Sedimentary Geology 49, 73-108.

Sebe, K., Csillag, G., Ruszkiczay-Rüdiger, Z., Fodor, L., Thamó-Bozsó, E., Müller, P., Braucher, R., 2011. Wind erosion under cold climate: A Pleistocene periglacial mega-yardang system in Central Europe (Western Pannonian Basin, Hungary). Geomorphology 134, 470-482.

Sebe, K., Roetzel, R., Fiebig, M., Lüthgens, C., 2015. Pleistocene wind system in eastern Austria and its impact on landscape evolution. Catena 134, 59-74.

Shao, Y., 2001. A model for mineral dust emission. Journal of Geophysical Research 106 (D17), 2023920254.

Sima, A., Kageyama, M., Rousseau, D.D., Ramstein, G., Balkanski, Y., Antoine, P., Hatté, C., 2013. Modeling dust emission response to North Atlantic millennial-scale climate variations from the perspective of East European MIS 3 loess deposits. Climate of the Past 9, 1385-1402. 
Sitzia, L., Bertran, P., Sima, A., Cherry, P., Queffelec, A., Rousseau, D.D., 2017. Dynamics and sources of last glacial aeolian deposition in southwest France derived from dune patterns, grain-size gradients and geochemistry, and reconstruction of efficient wind directions. Quaternary Science Reviews 170, 250-268.

Sitzia, L., Bertran, P., Bahain, J.J., Bateman, M., Hernandez, M., Garon, H., De Lafontaine, G., Mercier N., Leroyer C., Queffelec, A., Voinchet, P., 2015. The quaternary coversands of southwest France. Quaternary Science Reviews 124, 84-105.

Skurzyński, J., Jarya, Z., Kenisb, P., Kubikb, R., Moskac, P., Raczyka, J., Seuld, C., 2020. Geochemistry and mineralogy of the Late Pleistocene loess-palaeosol sequence in Złota (near Sandomierz, Poland): Implications for weathering, sedimentary recycling and provenance. Geoderma 375, 114459 (https://doi.org/10.1016/j.geoderma.2020.114459).

Smalley, I.J., 1966. The properties of glacial loess and the formation of loess deposits. Journal of Sedimentary Petrology 36(3), 669-676.

Smalley, I.J., Leach, J.A., 1978. The origin and distribution of the loess in the Danube Basin and associated regions of East-Central Europe - A review. Sedimentary Geology 21, 1-26.

Smalley, I., O'Hara-Dhand, K., Wint, J., Machalett, B., Jary, Z., Jefferson, I., 2009. Rivers and loess: The significance of long river transportation in the complex event-sequence approach to loess deposit formation. Quaternary International 198, 7-18.

Smalley, I., Marković, S.B., Svirčev, Z. 2011. Loess is [almost totally formed by] the accumulation of dust. Quaternary International 240, 4-11.

Smith, B.J., Wright, J.S., Whalley, W.B., 2002. Sources of non-glacial, loess-size quartz silt and the origins of "desert loess." Earth-Science Reviews 59, 1-26.

Strandberg, G., Brandefelt, J., Kjellström, E., Smith, B., 2011. High-resolution regional simulation of last glacial maximum climate in Europe. Tellus A: Dynamic Meteorology and Oceanography 63, 107125.

Stroeven, A.P., Hättestrand, C., Kleman, J., Heyman, J., Fabel, D., Fredin, O., Goodfellow, B.W., Harbor J.M., Jansen, J.D., Olsen, L., Caffee, M.W., Fink, D., Lundqvist, J., Rosqvist, G.C., Strömberg, B., Jansson, K.N., 2016. Deglaciation of Fennoscandia. Quaternary Science Reviews 147, 91-127.

Sümegi, P., Gulyás, S., Molnár, D., Sümegi, B.P., Almond, P.C., Vandenberghe, J., Zhou, L., Pál-Molnár, E., Töröcsik, T., Hao, Q., Smalley, I., Molnár, M., Marsi, I., 2018. New chronology of the bestdeveloped loess/paleosol sequence ofcHungary capturing the past 1.1 ma: Implications for correlation and proposed pan-Eurasian stratigraphic schemes. Quaternary Science Reviews 191, 144166.

Suter-Burri, K., Gromke, C., Leonard, K.C., Graf, F., 2013. Spatial patterns of aeolian sediment deposition in vegetation canopies: Observations from wind tunnel experiments using colored sand. Aeolian Research 8, 65-73.

Svenning, J.C., Normand, S., Kageyama, M., 2008. Glacial refugia of temperate trees in Europe: insights from species distribution modelling. Journal of Ecology 96, 1117-1127.

Svirčev, Z., Dulić, T., Obreht, I., Codd, G.A., Lehmkuhl, F., Marković, S., Hambach, U., Meriluoto, J., 2019. Cyanobacteria and loess - an underestimated interaction. Plant Soil 439, 293-308. 
Swet, N., Kok. J.F., Huang, Y., Yizhaq, H., Katra, I., 2020. Low dust generation potential from active sand grains by wind abrasion. Journal of Geophysical Research: Earth Surface 125, e2020JF005545. https://doi.org/10.1029/2020JF005545.

Thomas, P.J., Murray, A.S., Granja, H.M., Jain, M., 2008. Optical Dating of Late Quaternary Coastal Deposits in Northwestern Portugal. Journal of Coastal Research 24(2B), 134-144.

Tóth, G., Jones, A., Montanarella, L., 2013. LUCAS topsoil survey. Methodology, data and results. JRC Technical Reports, Publication Office of the European Union, Luxembourg, 141 pp.

Toucanne, S., Zaragosi, S., Bourillet, J.F., Cremer, M., Eynaud, E., Van Vliet-Lanoë, B., Penaud, A., Fontanier, C., Turon, J.L., Cortijo, E., Gibbard, P.L., 2009. Timing of massive 'Fleuve Manche' discharges over the last $350 \mathrm{kyr}$ : insights into the European ice-sheet oscillations and the European drainage network from MIS 10 to 2. Quaternary Science Reviews 28, 1238-1256.

Tsoar, H., Pye, K., 1987. Dust transport and the question of desert loess formation. Sedimentology $34,139-153$.

Újvári, G., Kok, J.F., Varga, G., Kovács, J., 2016. The physics of wind-blown loess: Implications for grain size proxy interpretations in Quaternary paleoclimate studies. Earth-Science Reviews 154, 247-278.

Újvári, G., Varga, A., Raucsik, B., Kovács, J., 2014. The Paks loess-paleosol sequence: A record of chemical weathering and provenance for the last $800 \mathrm{ka}$ in the mid-Carpathian Basin. Quaternary International 319, 22-37.

Újvári, G., Varga, A., Ramos, F.C., Kovács, J., Németh, T., Stevens, T., 2012. Evaluating the use of clay mineralogy, $\mathrm{Sr}-\mathrm{Nd}$ isotopes and zircon $\mathrm{U}-\mathrm{Pb}$ ages in tracking dust provenance: An example from loess of the Carpathian Basin. Chemical Geology 304-305, 83-96.

Vandenberghe, J., Krook, L., 1985. La stratigraphie et la genèse de dépôts pléistocènes à Goirle (PaysBas). Bulletin de l'Association française pour l'étude du quaternaire 22(4), 239-247.

Varga, A., Újvári, G., Raucsik, B., 2011. Tectonic versus climatic control on the evolution of a loesspaleosol sequence at Beremend, Hungary: An integrated approach based on paleoecological, clay mineralogical, and geochemical data. Quaternary International 240, 71-86.

Varga, A., Cserháti, C., Kovács, J., Szalai, Z., 2016. Saharan dust deposition in the Carpathian Basin and its possible effects on interglacial soil formation. Aeolian Research 22, 1-12.

Wacha, L., Pavlaković, S.M., Novothny, A., Crnjaković, M., Frechen, M., 2011. Luminescence dating of Upper Pleistocene loess from the Island of Susak in Croatia. Quaternary International 234, 50-61.

Wagner, B., 2011. Spatial analysis of loess and loess-like sediments in the Weser-Aller catchment (Lower Saxony and Northern Hesse, NW Germany). E\&G Quaternary Science Journal 60(1), 27-46.

Wieder, M., Gvirztman, G., Porat, N., Dassat, M., 2008. Paleosols of the southern coastal plain of Israel. Journal of Plant Nutrition and Soil Science 171, 533-541.

Woillez, M.N., Kageyama, M., Krinner, G., de Noblet-Ducoudré, N., Viovy, N., Mancip, M., 2011. Impact of $\mathrm{CO} 2$ and climate on the Last Glacial Maximum vegetation: results from the ORCHIDEE/IPSL models. Climate of the Past 7, 557-577. 
Wolf, D., Kolb, T., Alcaraz-Castaño, M., Heinrich, S., Baumgart, P., Calvo, R., Sánchez, J., Ryborz, K., Schäfer, I., Bliedtner, M., Zech, R., Zöller, L., Faust, D., 2018. Climate deteriorations and Neanderthal demise in interior Iberia. Scientific Reports 8, 7048 (https://doi.org/10.1038/s41598-018-25343-6).

Wolf, D., Ryborz, K., Kolb, T., Zapata, R.C., Vizcaino, J.S., Zöller, L., Faust, D., 2019. Origins and genesis of loess deposits in central Spain, as indicated by heavy mineral compositions and grain-size variability. Sedimentology 66, 1139-1161.

Wright, J., 2001. Making loess-sized quartz silt: data from laboratory simulations and implications for sediment transport pathways and the formation of 'desert' loess deposits associated with the Sahara. Quaternary International 76, 7-19.

Wright, J., Smith, B., Whalley, B., 1998. Mechanisms of loess-sized quartz silt production and their relative effectiveness: laboratory simulations. Geomorphology 23, 15-34.

Youssef, F., Visser, S.M., Karssenberg, D., Erpul, G., Cornelis, W.M., Gabriels, D., Poortinga, A., 2012. The effect of vegetation patterns on wind-blown mass transport at the regional scale: A wind tunnel experiment. Geomorphology 159-160, 178-188.

Zazo, C., Mercier, N., Silva, P.G., Dabrio, C.J., Goy, J.L., Roquero, E., Soler, V., Borja, F., Lario, J., Polo, D., de Luque, L., 2005. Landscape evolution and geodynamic controls in the Gulf of Cadiz (Huelva coast, SW Spain) during the Late Quaternary. Geomorphology 68, 269-290.

Zazo, C., Mercier, N., Lario, J., Roquero, E., Goy, J.L., Silva, P.G., Cabero, A., Borja, F., Dabrio, C.J., Bardají, T., Soler, V., García-Blázquez, A., de Luque, L., 2008. Palaeoenvironmental evolution of the Barbate-Trafalgar coast (Cadiz) during the last $\sim 140 \mathrm{ka}$ : Climate, sea-level interactions and tectonics. Geomorphology 100, 212-222.

Zeeberg, J., 1998. The European sand belt in Eastern Europe - and comparison of Late Glacial dune orientation with GCM simulation results. Boreas 27, 127-139.

\section{Table and figure captions}

Table 1: Target textures of the aeolian deposits.

Figure 1: Texture of European aeolian deposits. A - Points extracted from topsoil texture rasters in different areas of aeolian deposits; B - Samples of loess from northern France analysed by Lautridou (1985), compared to 500 points extracted from topsoil texture rasters (Ballabio et al., 2016) in the zone of loess with a thickness greater than $4 \mathrm{~m}$.

Figure 2: Target textures of aeolian deposits according to regions.

Figure 3: Random points extracted from topsoil texture rasters (Ballabio et al., 2016) in loess from northern France, Germany, Italy, the Lower Danube Basin and the Rhône Valley. A - Percentage of coarse fragments; B - Percentage of clay.

Figure 4: Map of European aeolian deposits. The 21 ka ice sheets are taken from Hughes et al. (2016) for FIS and BIIS and from Ehlers and Gibbard (2004) for the rest of Europe. The $15 \mathrm{ka}$ ice sheets are from Clarke et al. (2012) for BIIS and Stroeven et al. (2016) for FIS. AL - Albania, AU - Austria, BEBelgium, BO - Bosnia Herzegovina, BU - Bulgaria, CR - Croatia, CZ - Czech Republic, DE - Denmark, 
1000 FR - France, GE - Germany, GR - Greece, HU - Hungary, IT - Italy, NE - the Netherlands, PO -

1001 Portugal, RO - Romania, SE - Serbia, SL - Slovakia, SP - Spain, UK - United Kingdom.

1002 Figure 5: Comparison of the distribution of loess and sandy loess in this study and Lehmkuhl et al.

1003 (2021). Common areas are in red.

1004 Figure 6: Distribution of loess in the Cotentin (NW France) according to this study, the 1:50,000

1005 geological map (BRGM) and Lehmkuhl et al. (2021), compared with the observed loess sections

1006 (Coutard et al., 2005).

1007 Figure 7: Comparison between maps and observation points in the Cotentin region. A - Percentage of 1008 points with loess or without loess well classified according to maps; the thickness indicated 1009 corresponds to the average thickness of the observed loess (points without loess excluded); B 1010 Average loess thickness all points combined.

1011 Figure 8: Distribution of coversands (this study), till and fluvio-glacial alluvium (http://www.europe1012 geology.eu/onshore-geology/) in northern Europe.

1013 Figure 9: Map of loess thickness. A - Total loess thickness; B - Last Glacial loess.

1014 Figure 10: Evolution of the percentage of sand in loess as a function of the distance to the coversands 1015 for 2 profiles extracted from the rasters of topsoil texture (Ballabio et al., 2016).

1016 Figure 11: Map of the main mode of MIS 2 loess, according to different authors.

1017 Figure 12: Grain size distribution of coversands, sandy loess and loess from different European 1018 regions. Aur: Auriac, Bou: Bourg-sur-Gironde, Mar: Marsas, SGe: Saint-Gein, after Sitzia et al. (2017); 1019 Cug: Cuges-les-Pins, Fey: Feyzin, Lau: Lautagne, Mau: Mauves-sud, after Bosq et al. (2018); Ach: 1020 Achenheim, after M. Bosq (unpublished); BK: Bialy Košciòl, Tys: Tyszowze, after Z. Jary (unpublished); 1021 Buh: Bůhzdař, after K. Flasarova (unpublished), Gra: Grafenberg 2, after Fischer et al. (2019). 

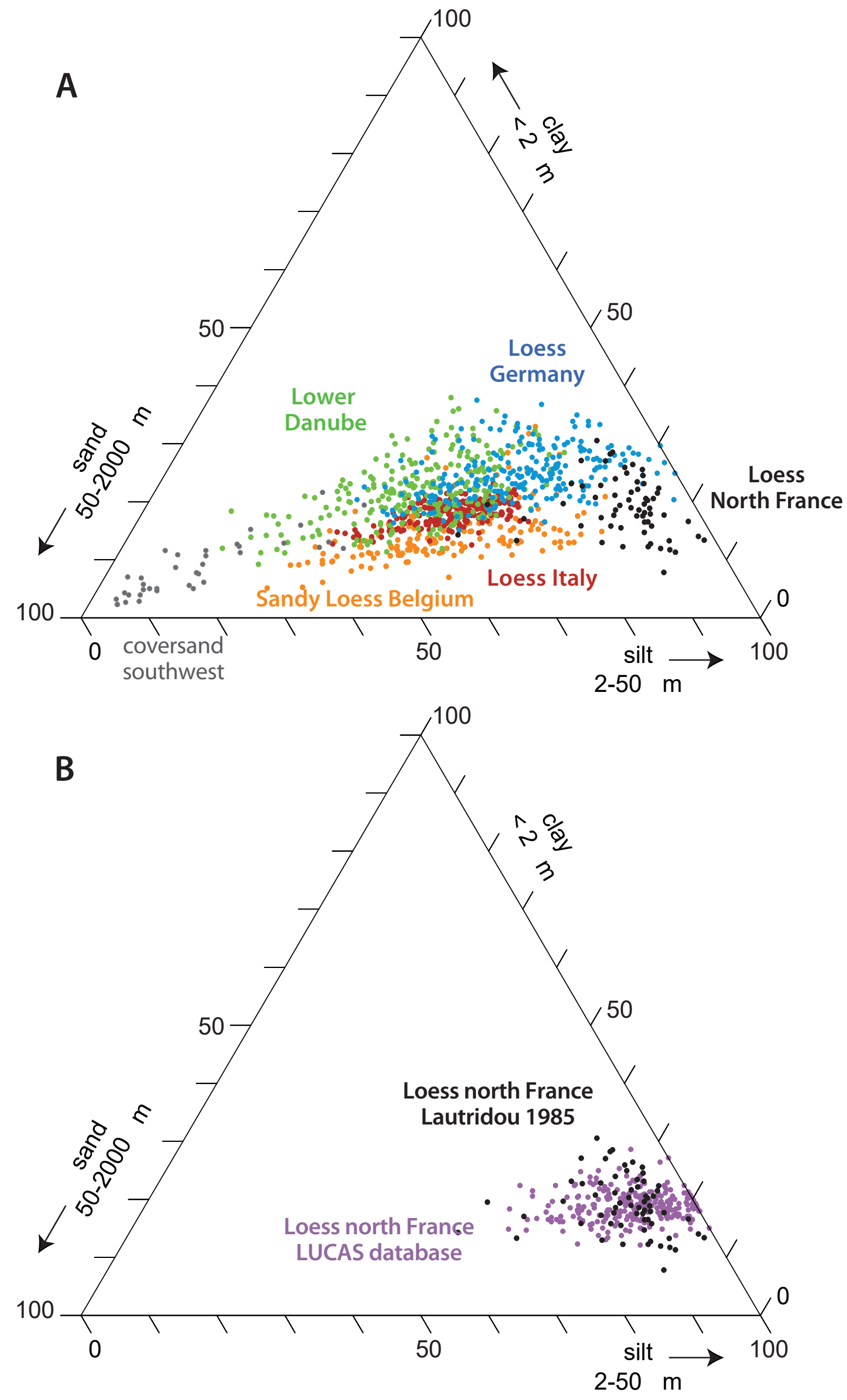


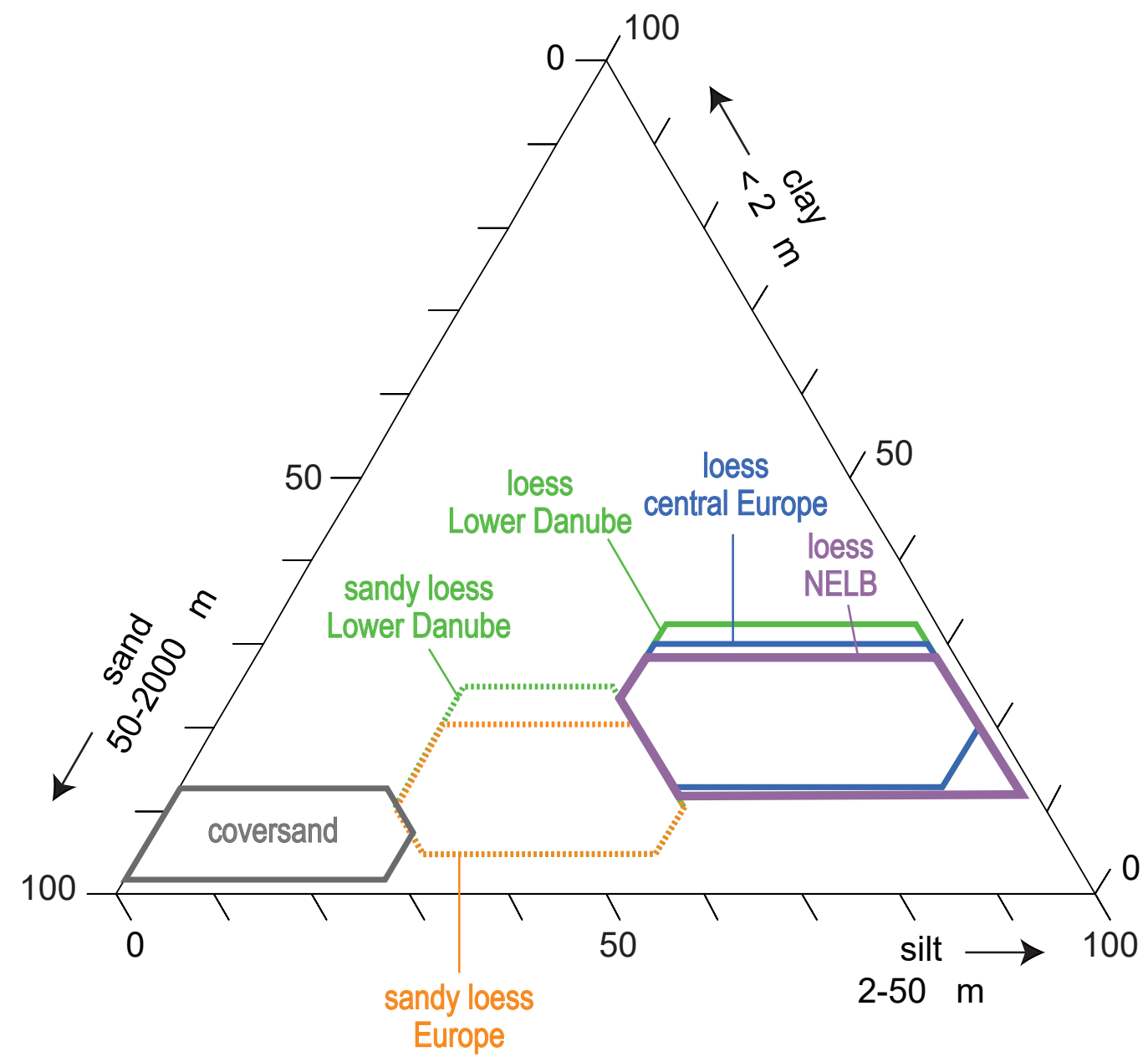


A

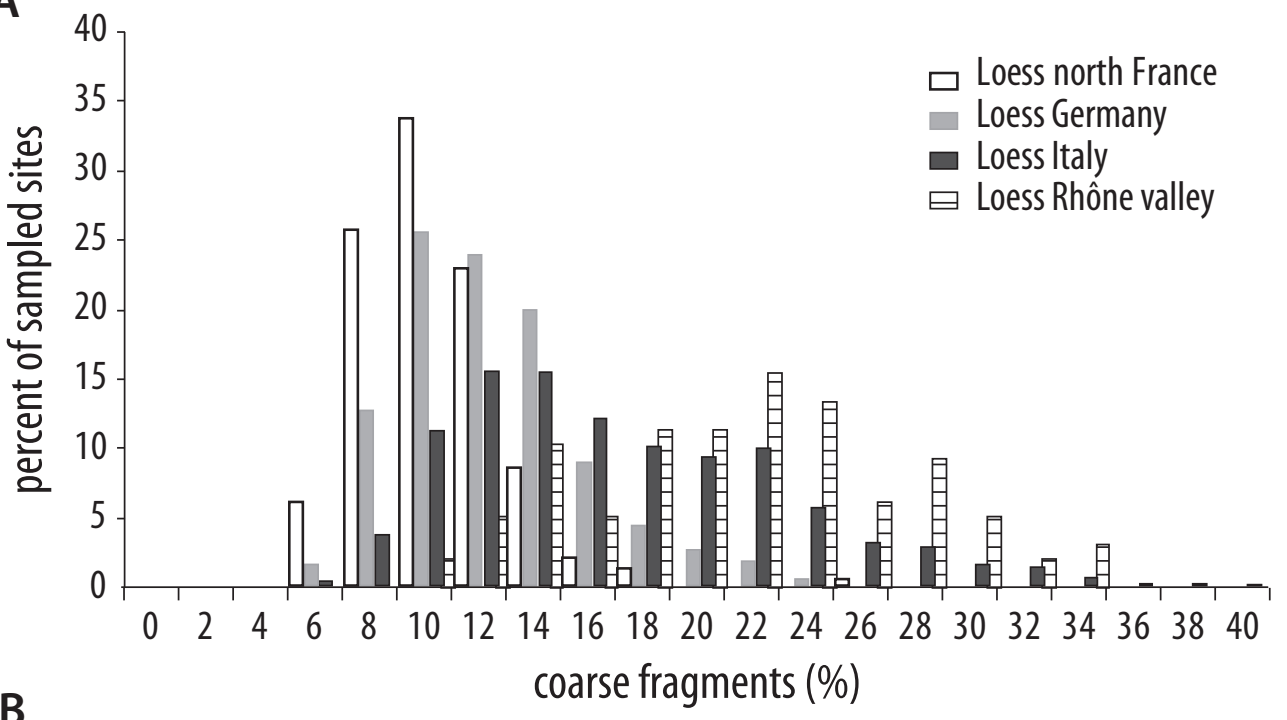

B

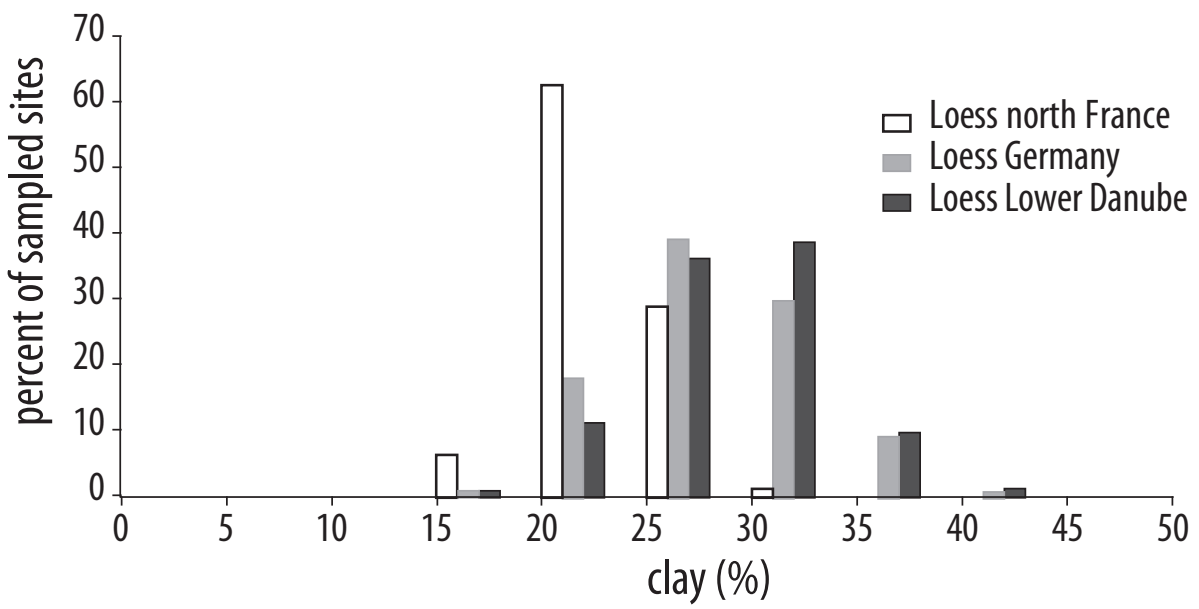




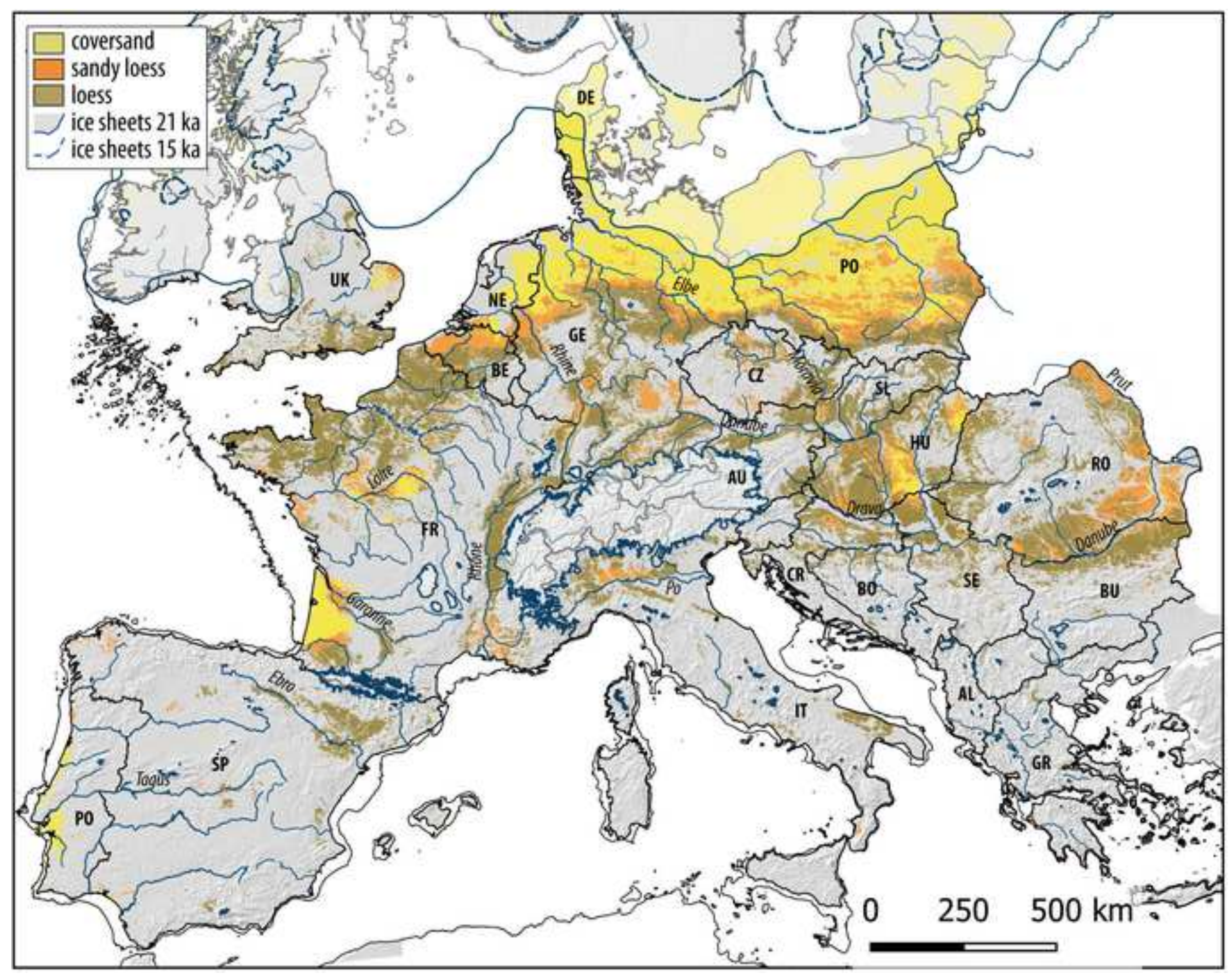




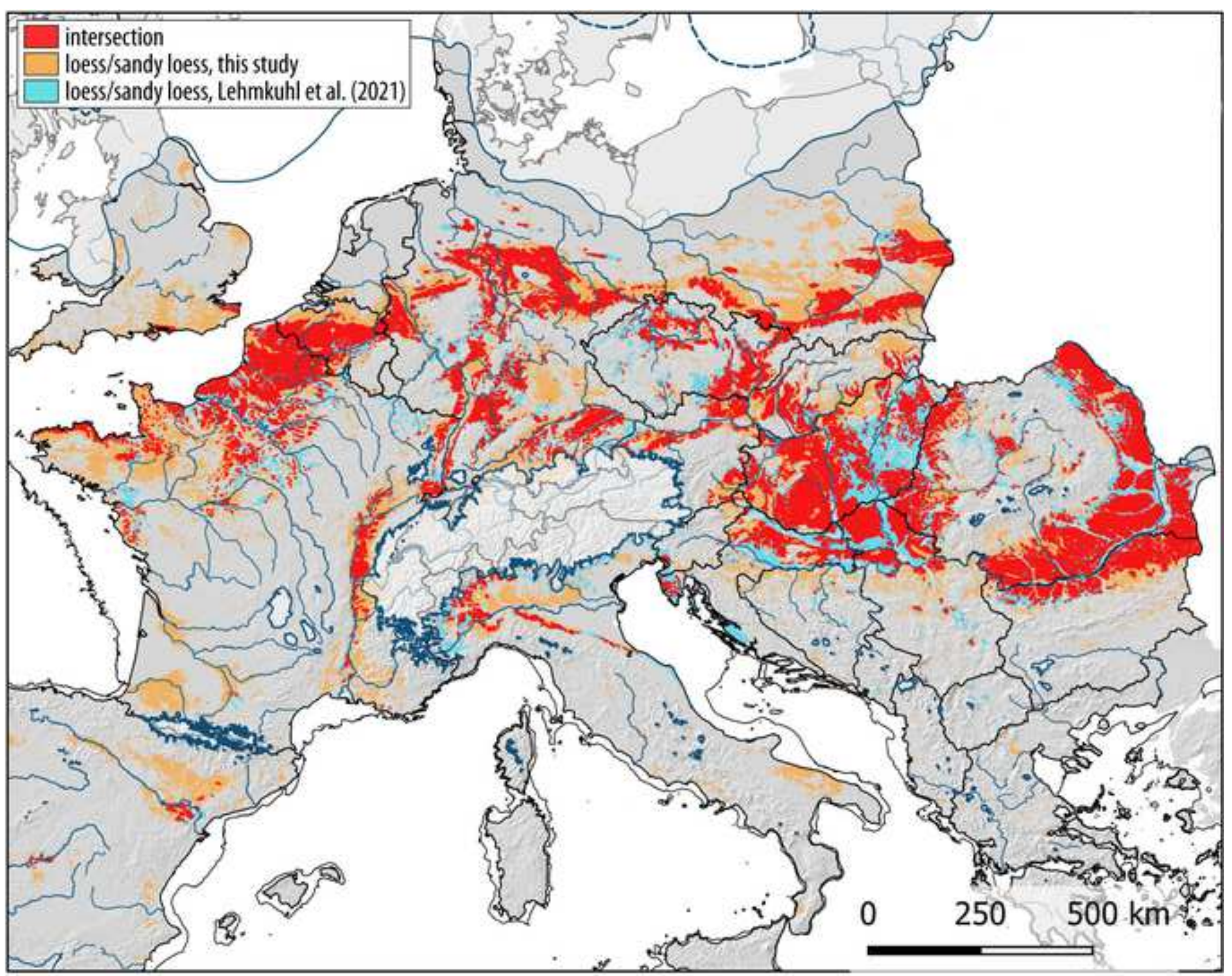




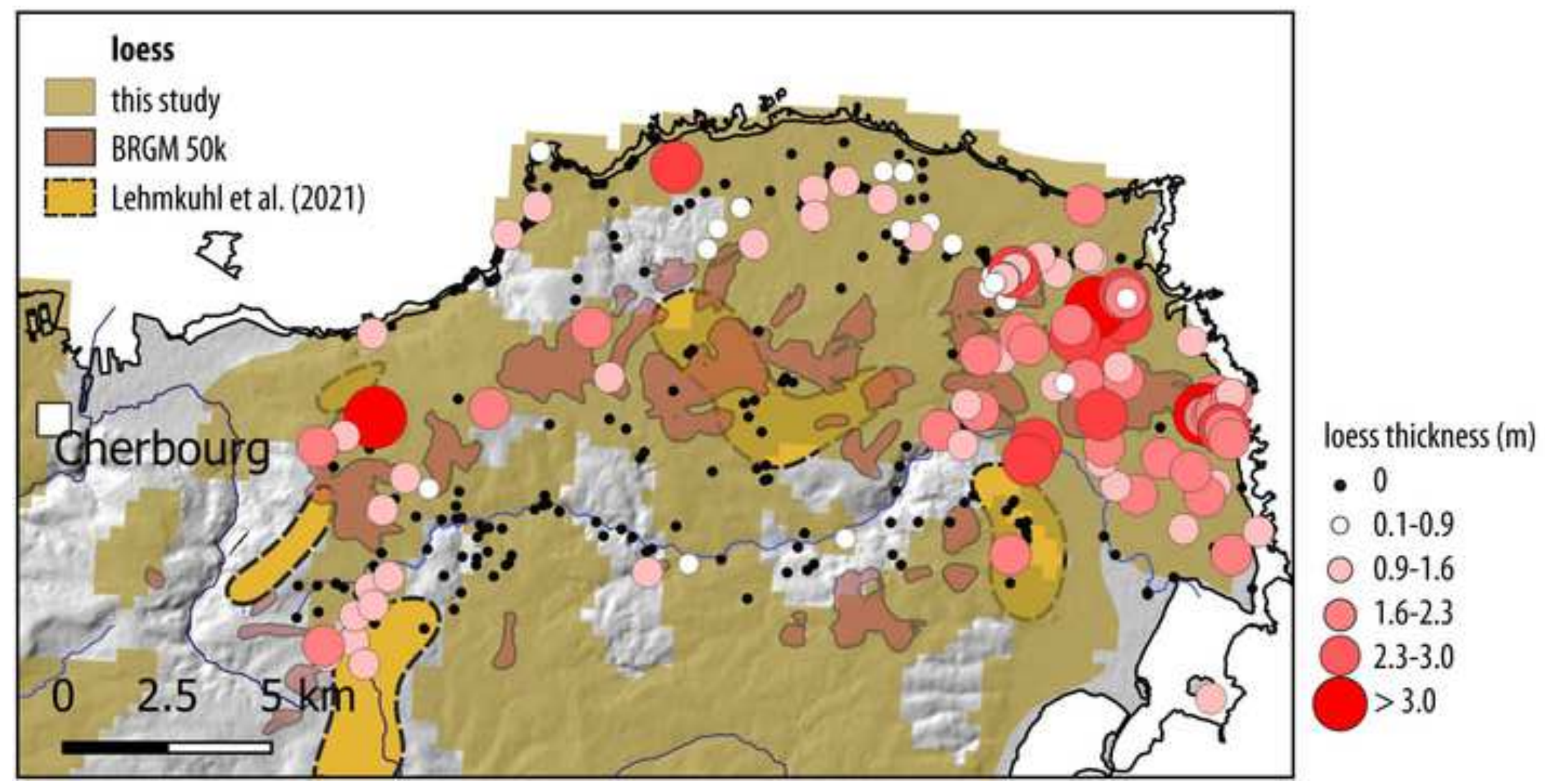




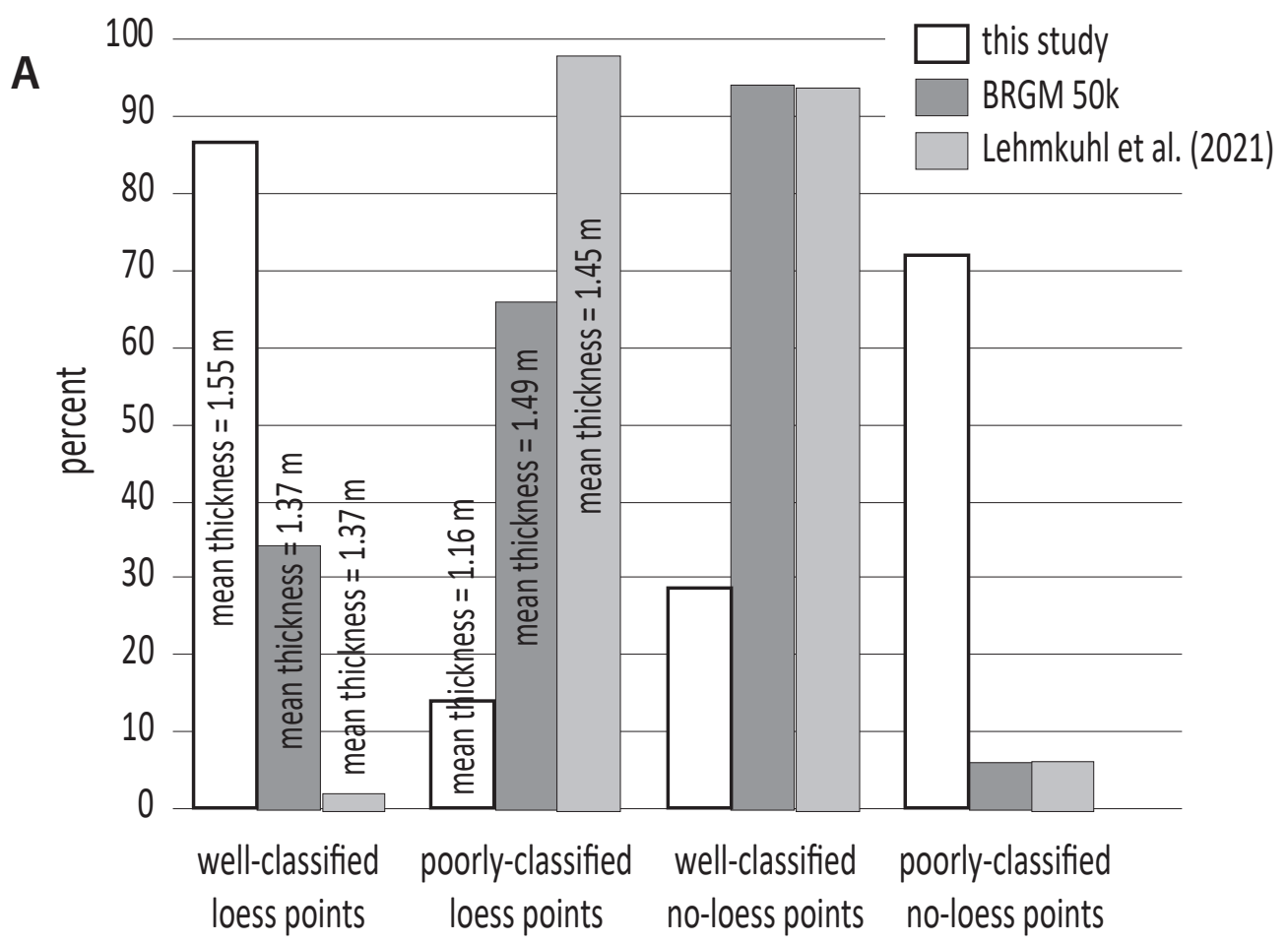

B

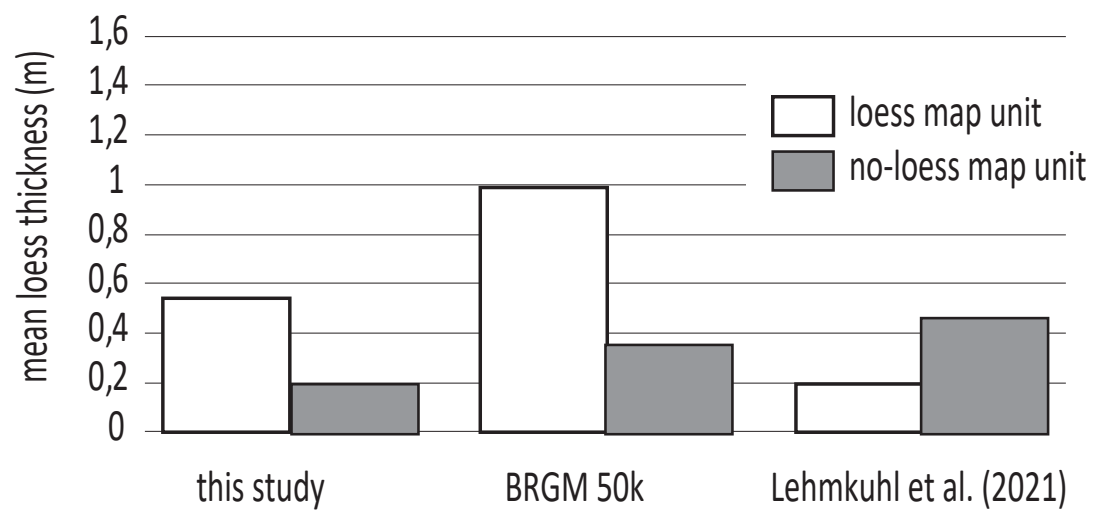




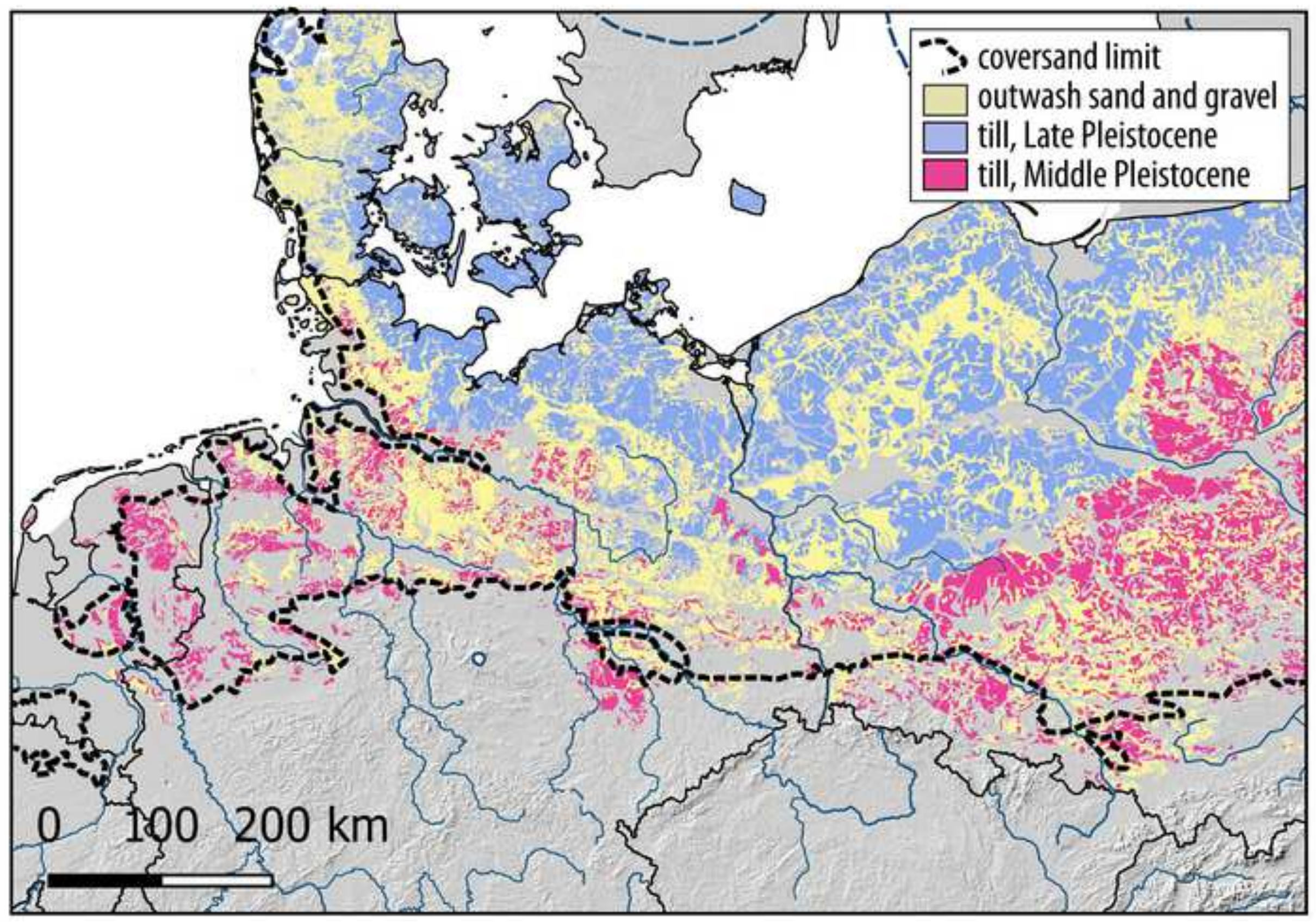



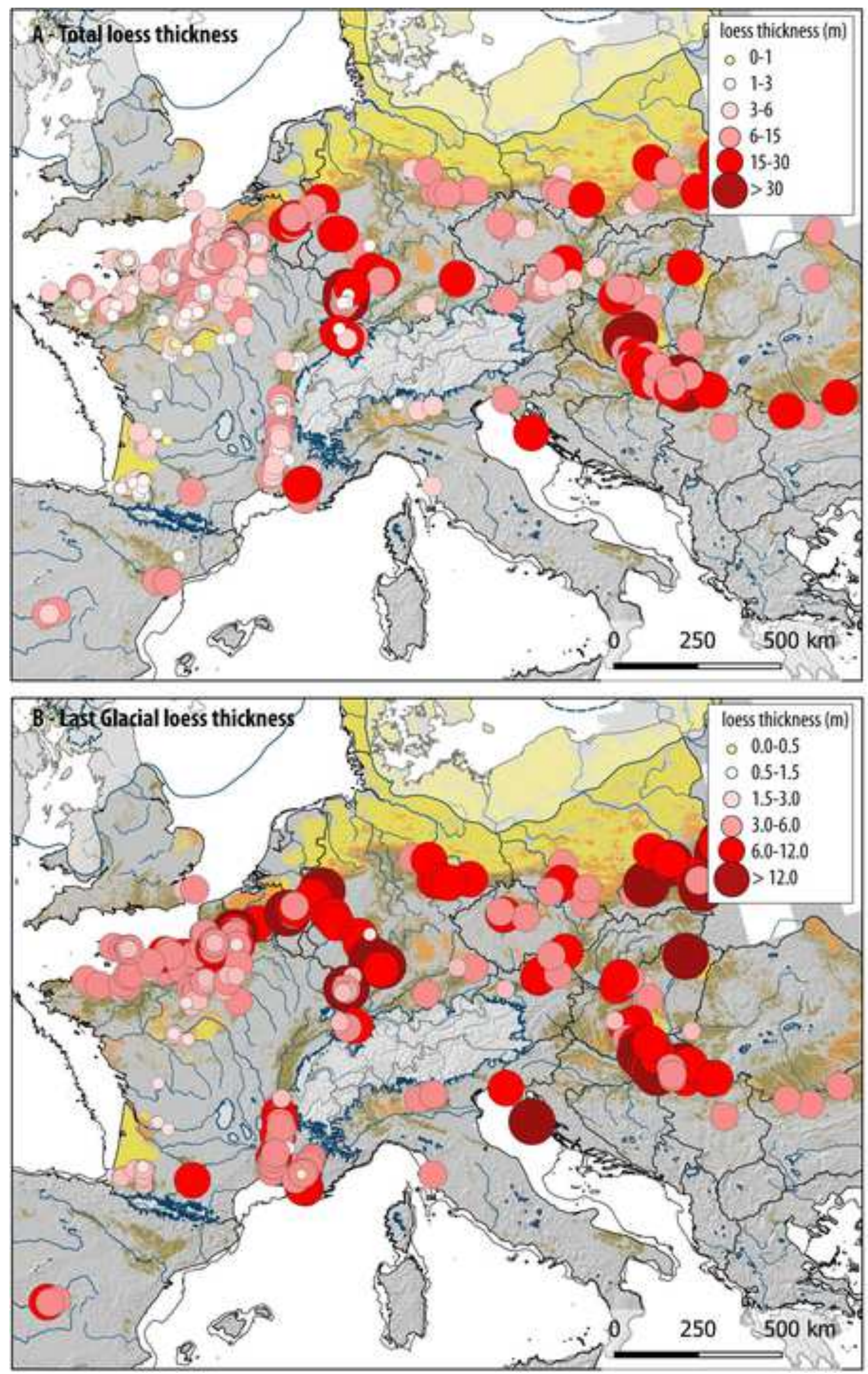


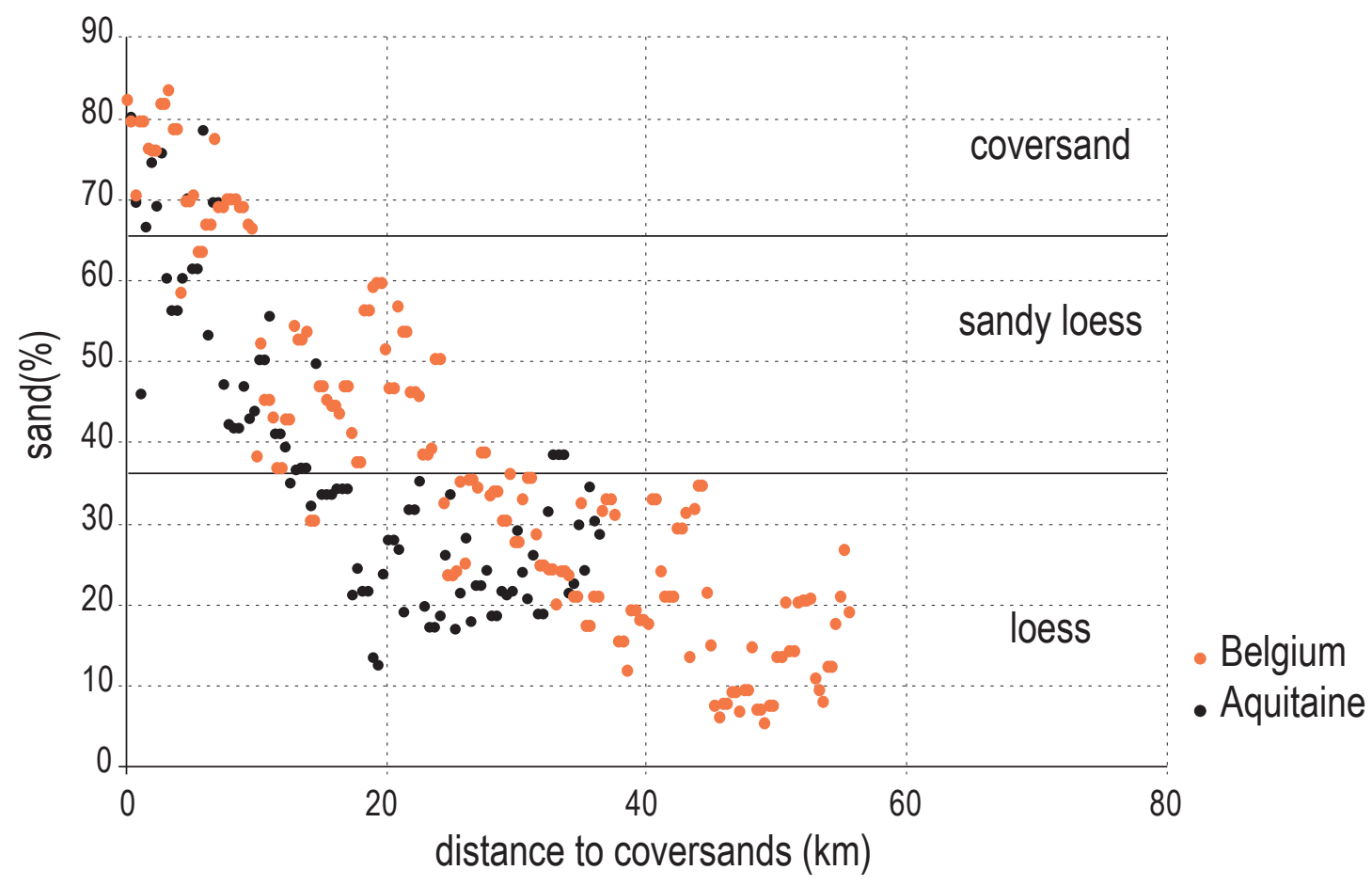




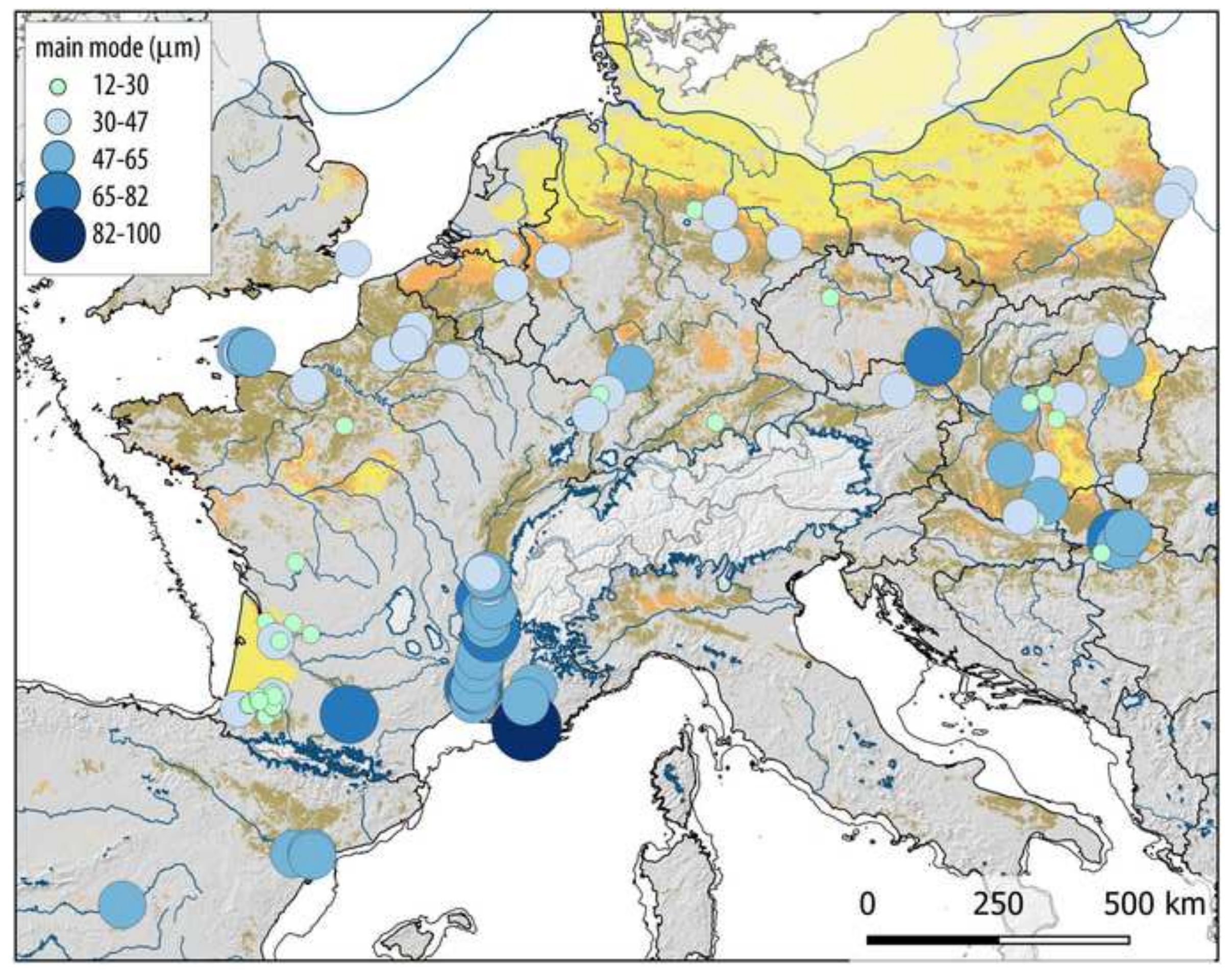



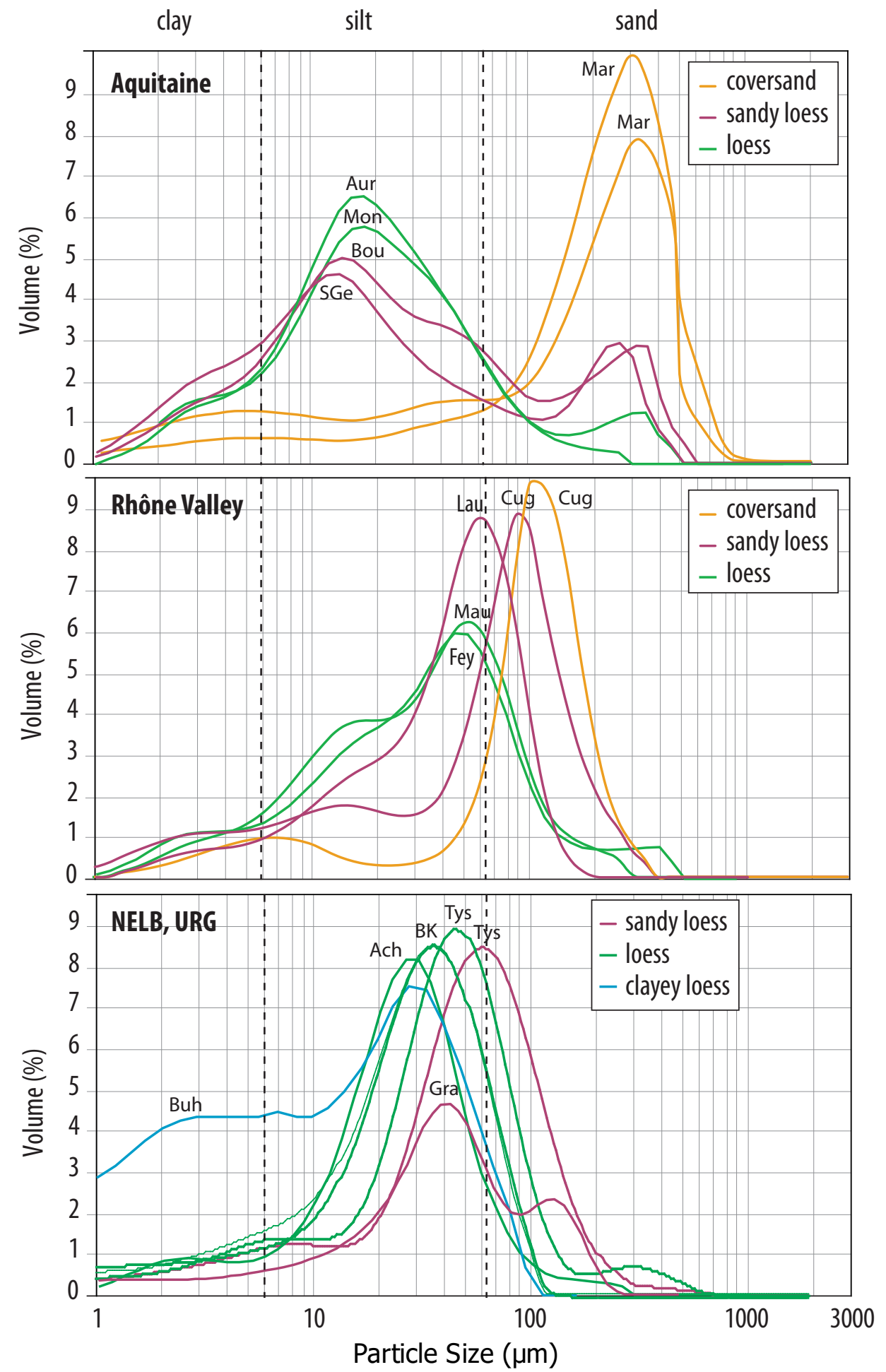
Loess NELB

Loess UK

Loess central Europe

loess Lower Danube Basin

Loess Po Plain

Loess Rhône Valley

Sandy loess NELB-central Europe

Sandy loess Lower Danube Basin

Sandy loess Rhône Valley

Coversand

$\begin{array}{llll}\text { clay (\%) } & \text { silt (\%) } & \text { sand (\%) } & \text { coarse (\%) } \\ 12-28 & 40-78 & 3-37 & <13 \\ 12-28 & 40-78 & 3-37 & <18 \\ 12-30 & 40-78 & 3-37 & <13 \\ 12-33 & 40-78 & 3-37 & <13 \\ 12-33 & 40-78 & 3-37 & <18 \\ 12-33 & 40-78 & 3-37 & <20 \\ 5-20 & 23-53 & 37-67 & <12 \\ 5-26 & 23-53 & 37-67 & <12 \\ 5-26 & 23-53 & 37-67 & <20 \\ 2-13 & 0-27 & 66-100 & <12\end{array}$




\section{Click here to access/download e-Component/Supplementary data Loess_Europe_sections_EPSG3035.xIsx}


Click here to access/download e-Component/Supplementary data Aeolien_Europe_EPSG3035.7z 